Publication 1390

Revised 1975

\title{
Farm \\ and \\ Ranch \\ Equipment \\ for \\ Beef Cattle
}

630.4

C212

P 1390

1975

c. 3

Nthy Agriculture

Canada 
Copies of this publication may be obtained from INFORMATION DIVISION

CANADA DEPARTMENT OF AGRICULTURE OTTAWA

K1A OC7

OINFORMATION CANADA. OTTAWA. 1975

Printed 1969

Reprinted 1972

Revised 1975

$10 \mathrm{M}-38150-8: 75$

Cat. No. : A53-1390 


\section{CONTENTS}

Corrals ............................. 6

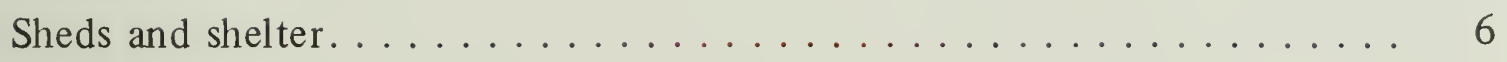

Loading chutes .......................... 6

Cattle chute ... . . . . . . . . . . . . . . . . . . . . . 13

Cattle squeeze........................... 13

Portable feed bunks and racks . . . . . . . . . . . . . . 13

Self-feeders . . . . . . . . . . . . . . . . . . . . 17

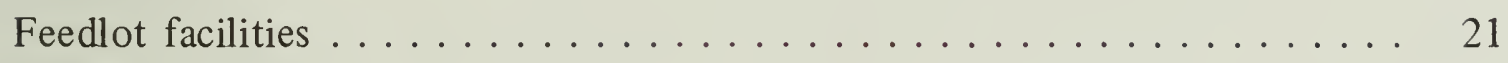

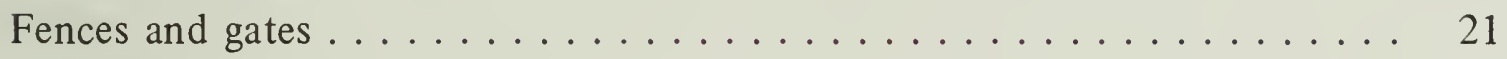

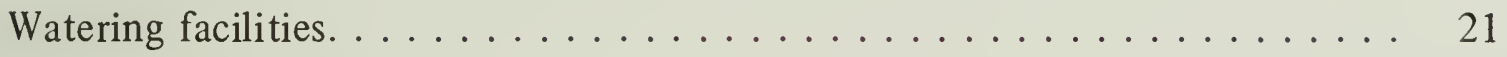

Silos ............................ 22

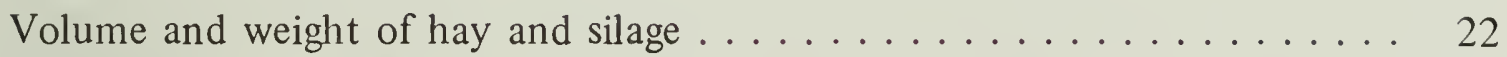

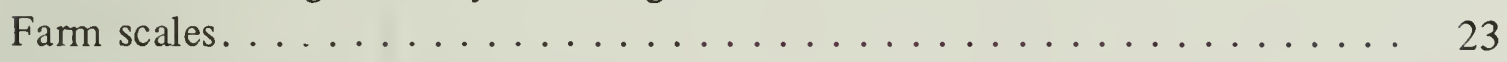

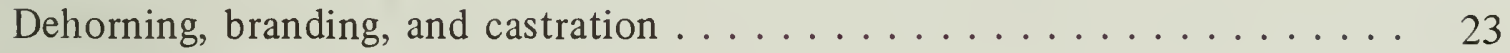

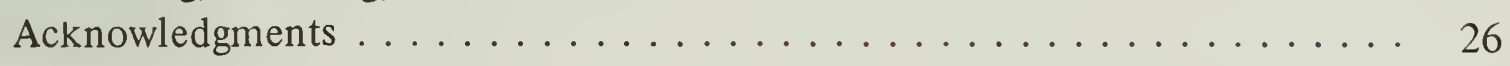


Digitized by the Internet Archive in 2012 with funding from

Agriculture and Agri-Food Canada - Agriculture et Agroalimentaire Canada 


\title{
FARM AND RANCH EQUIPMENT FOR BEEF CATTLE
}

\author{
WILLIAM A. HUBBARD \\ Research Station, Kamloops, British Columbia
}

It pays to build well-planned farm and ranch equipment. Well-designed corrals and other devices make handling of stock easier, save labor, and most important of all, cut shrinkage to a minimum. No single plan for equipment such as corrals, scales, chutes, squeezes, and dipping vats is suitable for every ranch. But certain features of construction are desirable for both ranch and farm. A good set of corrais should have adequate facilities for processing livestock. Drinking water should also be available. In certain areas shade and some shelter from the weather are desirable.

To be practical, useful, and efficient, any piece of cattle equipment must have some essential features. Other features are desirable and add to the value.

The essential features are:

- Simple construction Since cattle equipment is usually made by unskilled or semiskilled labor on the farm, it must be simple to build. Simple construction avoids the use of a large amount of material. It saves labor, and it permits joints and fastenings that give strength and stability.

- Strength Feeding equipment receives rough usage because the animals push and crowd at feeding time. All equipment should be built strongly and securely enough to resist the strain placed upon it.

- Dependability To be efficient, farm and ranch equipment must do its work without getting out of order.

Desirable features are:

- Reasonable cost The cost of equipment can often be kept down by using second-hand or locally obtained material.

- Low upkeep cost Cattle equipment should require very little upkeep. Examine it frequently to see that it is in good order. Replacing a broken part at once prevents further damage by the animals and puts the equipment into condition for use at a slight expense.

- Mobility Cattle equipment to be used outside should be built so that it will resist damage. Portable feed bunks should be constructed on skids for ease in moving. They should be low, heavy, and wide to prevent tipping or excessive movement.

- Access The location and shape of a rack, bunk, or manger should allow easy management by a ranch hand and ready access by the animals.

- Durability To prevent quick decay the posts resting on the ground should be creosoted. A little care in selecting durable, weather-resisting woods adds to the life of the equipment. 


\section{CORRALS}

A well-planned corral (Figure 1) should make it possible to process cattle with the least labor and cost. Certain features are essential.

- Build it on a convenient site, in a well-drained area.

- Make it strong enough to hold the animals.

- Have it arranged so that the animals can be quickly and easily sorted.

- Build strong loading and cutting chutes with smooth sides and protected corners to prevent bruising and crippling of the animals.

- Provide facilities for branding, dehorning, loading, unloading, weighing, dipping, spraying, sorting, and working cattle.

- Use materials most economically available, for example, poles instead of lumber.

- Avoid pockets and square turns. Posts used in construction should be treated to preserve them. Set them 6 to 8 feet apart and at least $21 / 2$ feet in the ground. Set the posts on the outside of corral fences first, with the smooth surface on the inside. Pad or round off all corners. Old auto tires work well for this purpose.

\section{SHEDS AND SHELTER}

Beef cattle can withstand extreme cold if they are kept dry. In fact, many animals choose to bed down in the open rather than under shelter if the weather is cold but dry and still. But in producing feeder cattle and fattening cattle for market, shelter that will give protection during severe cold and stormy weather (Figure 2) should be provided. For details, see Canada Plan Service, leaflet and plan no. 1453. Sheds with southern exposure, or those built against the prevailing wind, usually provide satisfactory shelter for beef cattle. In open sheds in a feedlot, allow 20 to 30 square feet of space per head for calves and 40 to 50 square feet for older cattle. Figure 3 illustrates a shed built of plywood, poles, and aluminum roofing, all of which are readily available. The sides and back are closed in and the front is open. For details, see Canada Plan Service, leaflet and plan no. 8162.

On ranches that produce large numbers of cattle for meat, windbreaks afford protection from disagreeable winds. They are especially desirable in pastures that are used for winter grazing where there is little or no protection. A suitable windbreak (Figure 4) may be constructed of 3/8-inch plywood or 28-gauge corrugated metal to form a solid fence, or of 1-inch boards to form an open fence. An open fence provides protection at least twice as far down wind as a solid fence. Studies at Saskatoon, Sask., indicate that on the leeward side a distance five times the height of the fence is protected from the wind.

\section{LOADING CHUTES}

Loading chutes are of two types, portable and stationary. The one illustrated in Figure 5 is a portable type although it could easily be nailed into position to make it stationary. The slope of the ramp should be kept as low as space will permit. Animals load or unload easier and slip less on a gentle slope. Some ranchers 


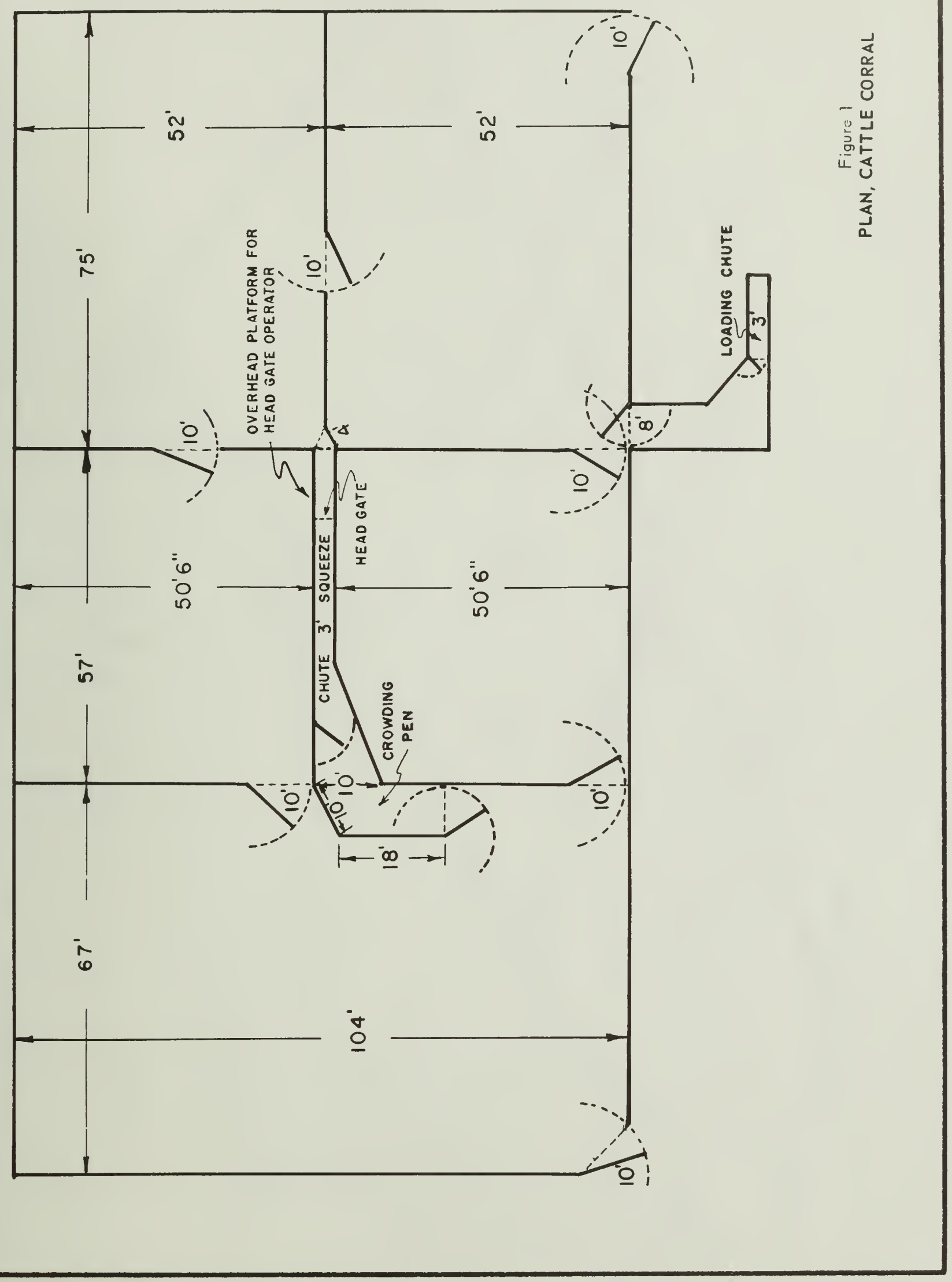




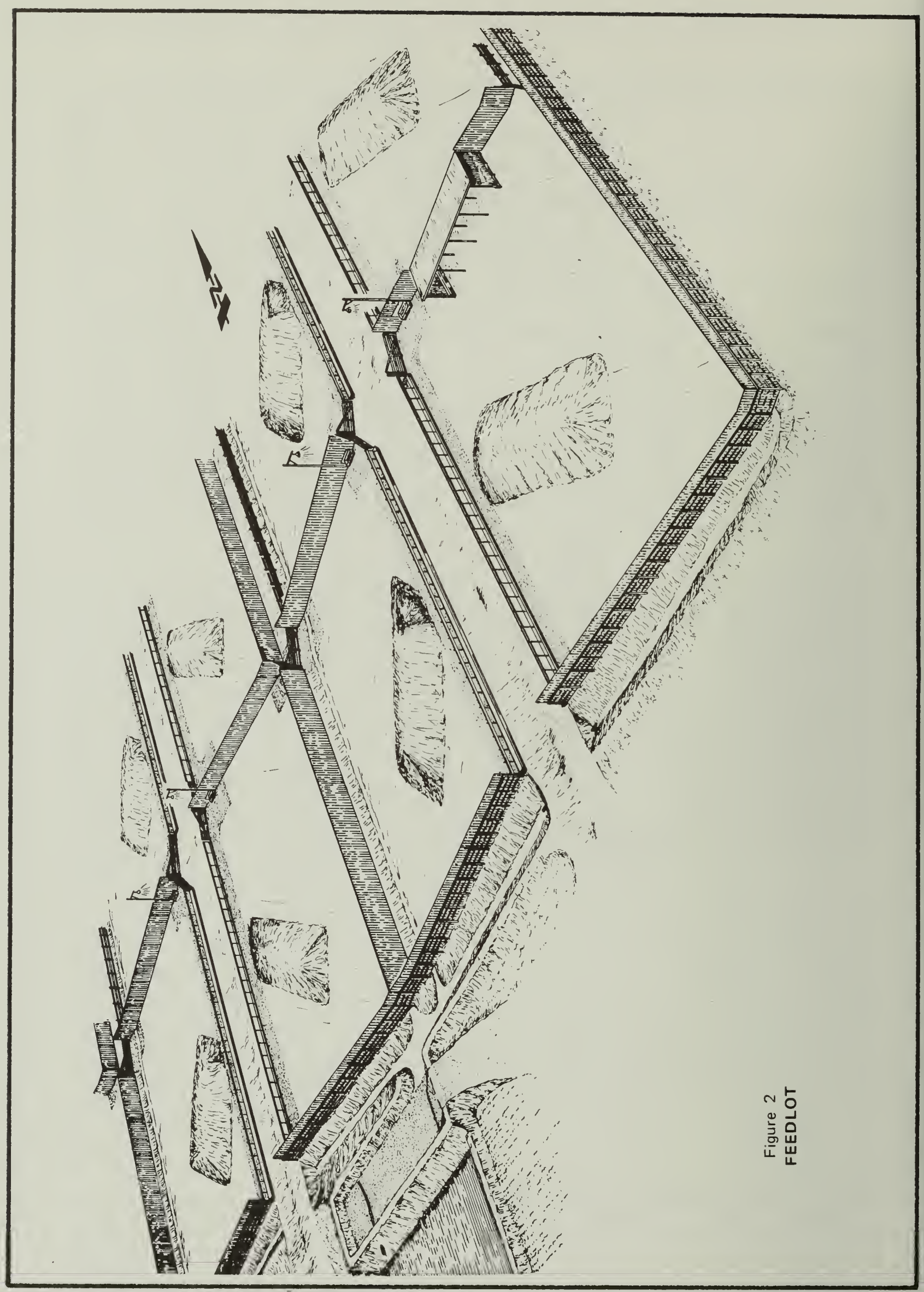




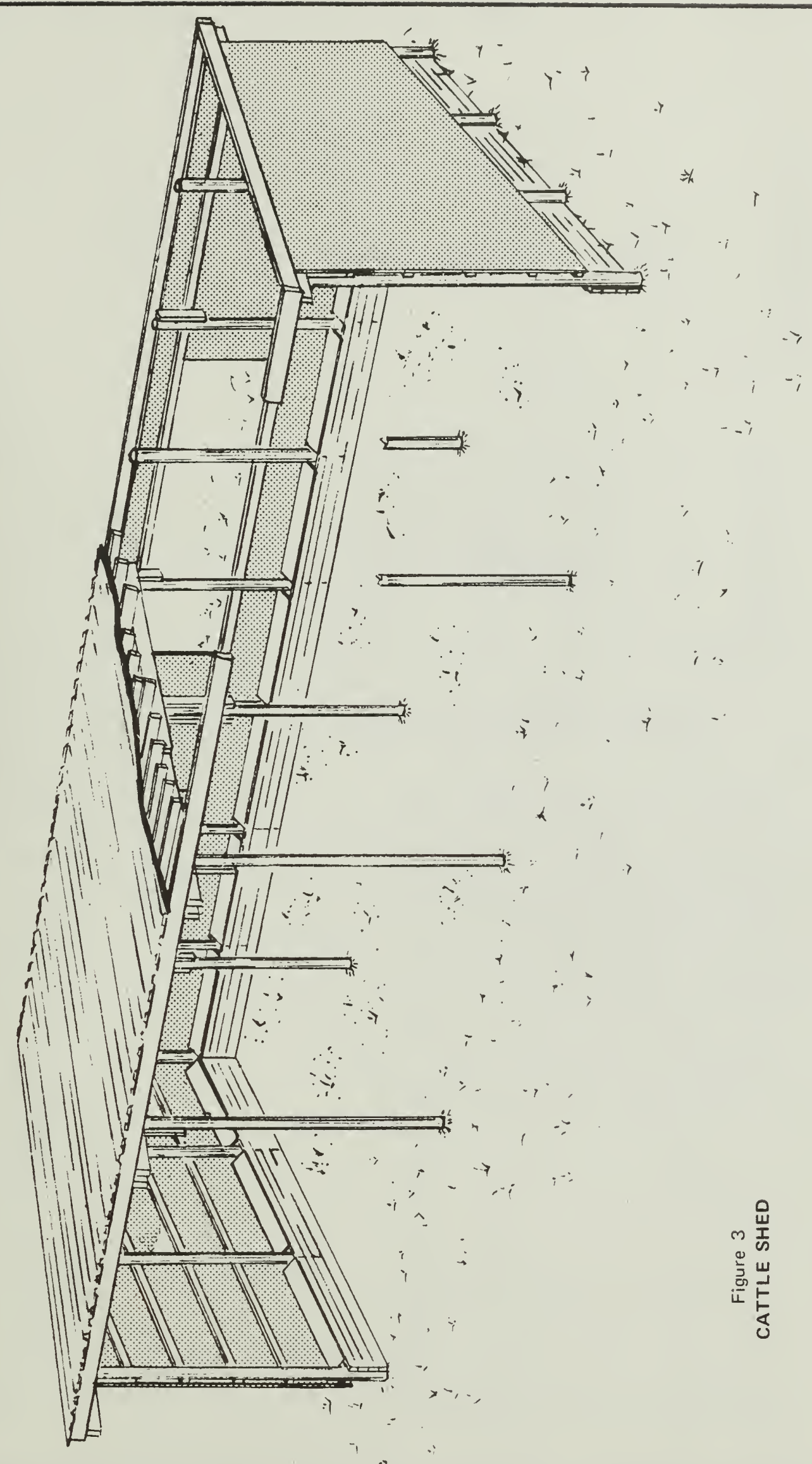



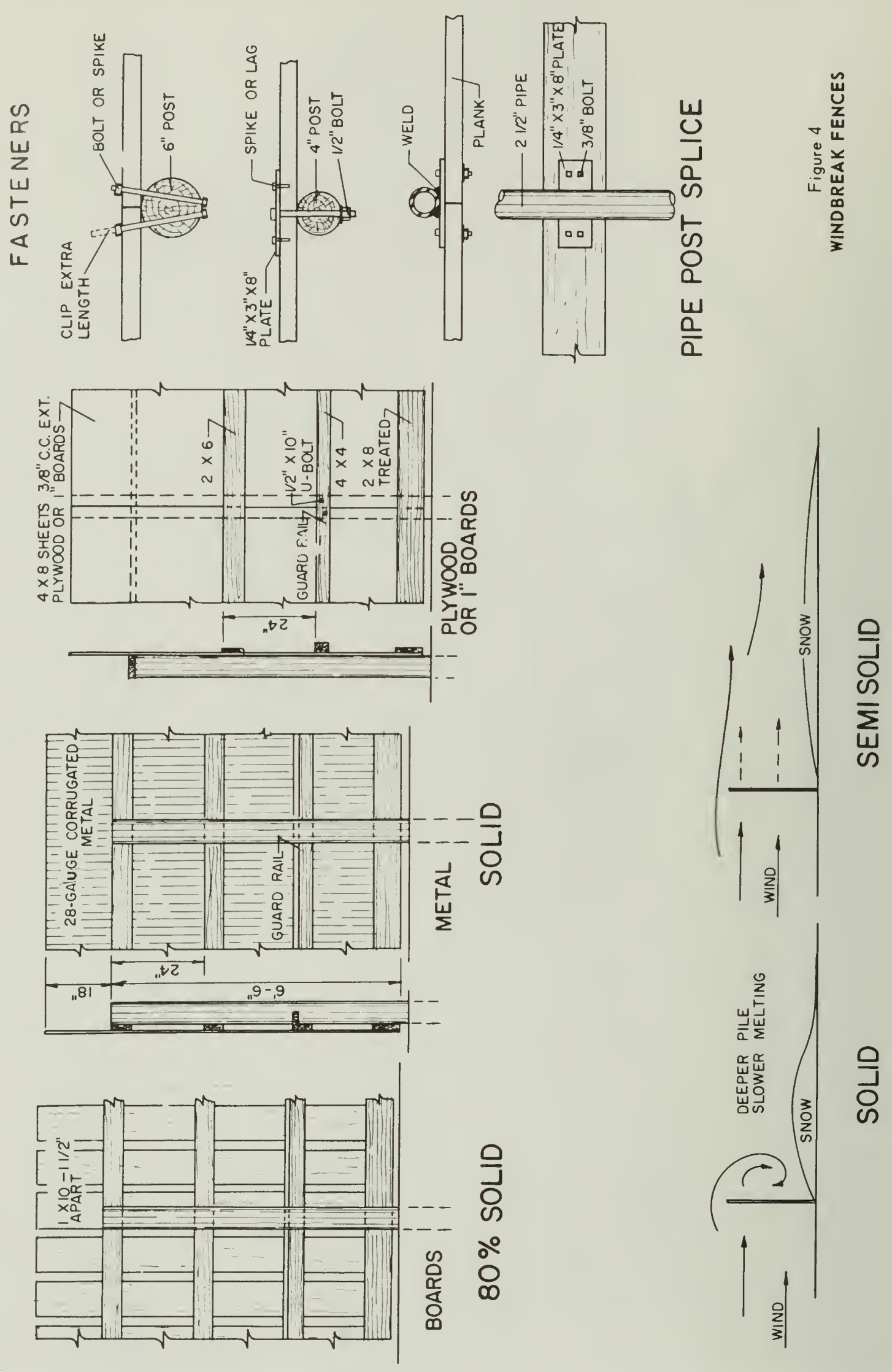


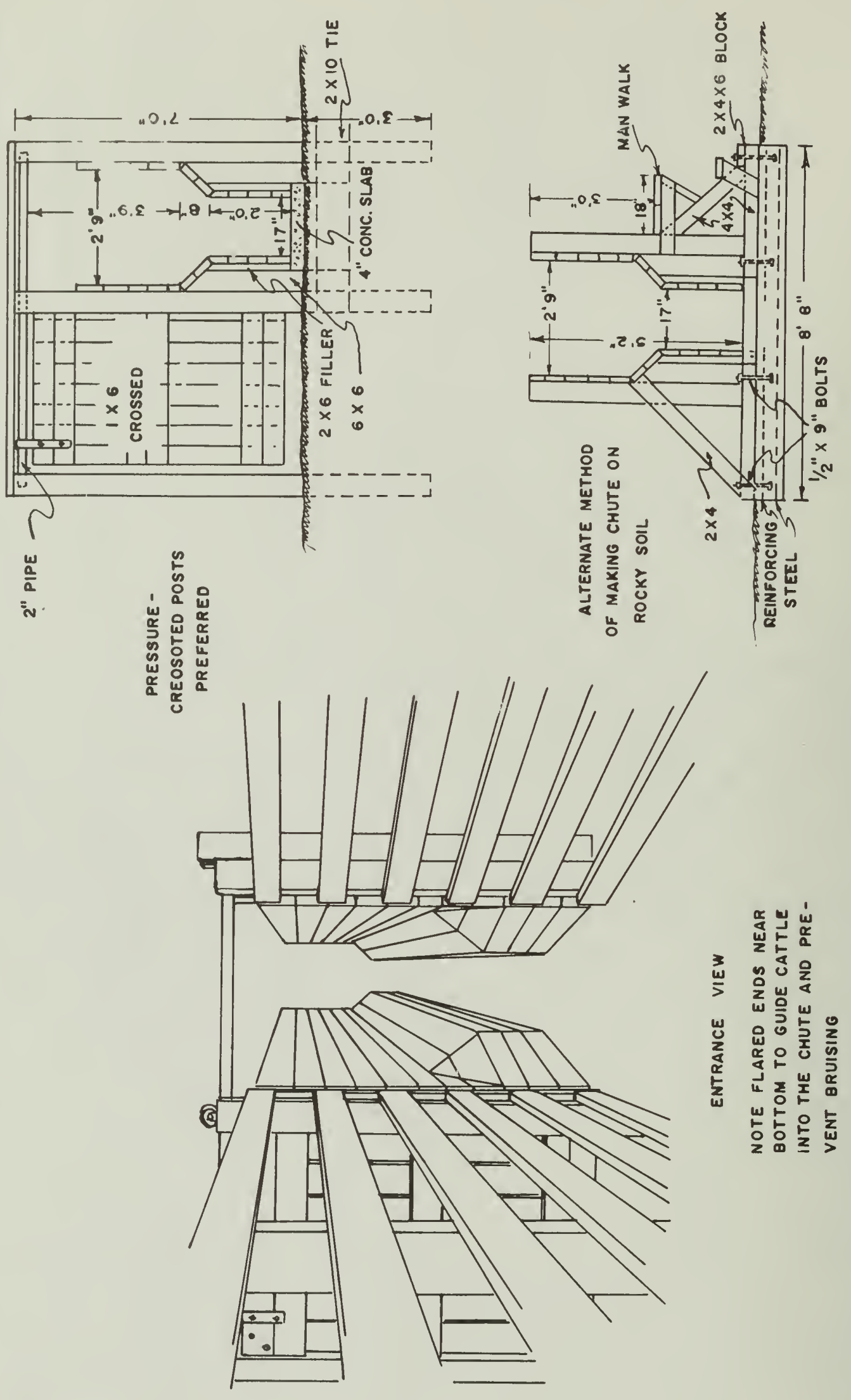

竞 
even build stair-tread types of ramps using $2 \times 10$ inch treads and $2 \times 4$ inch risers. The chute should be as narrow as possible to accommodate the animals that will be using it. In some cases this may be 28 inches, in others 36 inches. Some ranchers prefer tight sides on the loading chute, because they reduce chances of outside distraction, and the cattle being loaded or unloaded move forward more readily.

\section{CATTLE CHUTE}

A working chute and head gate save time, labor, and possible injury to the cattle when they must be restricted. The chute can be built with flaring or straight sides, or a combination of both (Figure 6). A chute with flaring sides should be 14 inches wide at the bottom, about 27 inches wide at a height of 3 feet, and 40 inches wide at a height of 5 feet. A straight-sided chute should be 24 inches wide for dehorned cattle and 30 inches wide for purebreds with horns. For both kinds of chutes, it is best to plank both sides solid for the first $31 / 2$ feet. When cracks are left between the planks, the cattle sometimes kick through the open spaces and injure their feet and legs. A man walk built along the left side facing the same direction as the cattle move in the chute makes for easier driving. The man walk should be not less than 18 inches wide and about 26 inches above ground level. To accommodate four or five animals, the chute leading from the pens to the head gate should be about 30 feet long. This length prevents delays, speeds up jobs such as dehorning, and in general allows the best use of available help.

There are many types of head gates used today. The type shown in Figure 7 is used by many ranchers and works well in corral layouts. It is hinged so that it can be swung open to release the animal. This type of head gate takes the place of a release gate.

\section{CATTLE SQUEEZE}

The pinch gate and squeeze gate are built on essentially the same plan as the chute, except that one side is hinged. The squeeze holds the animals tighter than the stanchion alone does. All these devices should be strong and easy to operate, since it is often necessary when confining an animal to close and fasten the gate in a fraction of a second. Buying an all-metal squeeze from a livestock supply house is sometimes a wise investment. It is an efficient type, although the noisy operation of the metal components is undesirable around wild cattle.

\section{PORTABLE FEED BUNKS AND RACKS}

Portable bunks for feeding silage and concentrate in the corral need to be wide and heavy enough to prevent tipping. They should be made out of 2 -inch material. The legs should be cut from $4 \times 4$ inch material and should be both bolted and braced to the body of the bunk. Figure 8 shows a good method of bracing the legs. This bunk can be moved by lifting it with a front-end loader, or by attaching $4 \times 4$ inch skids to the legs. 


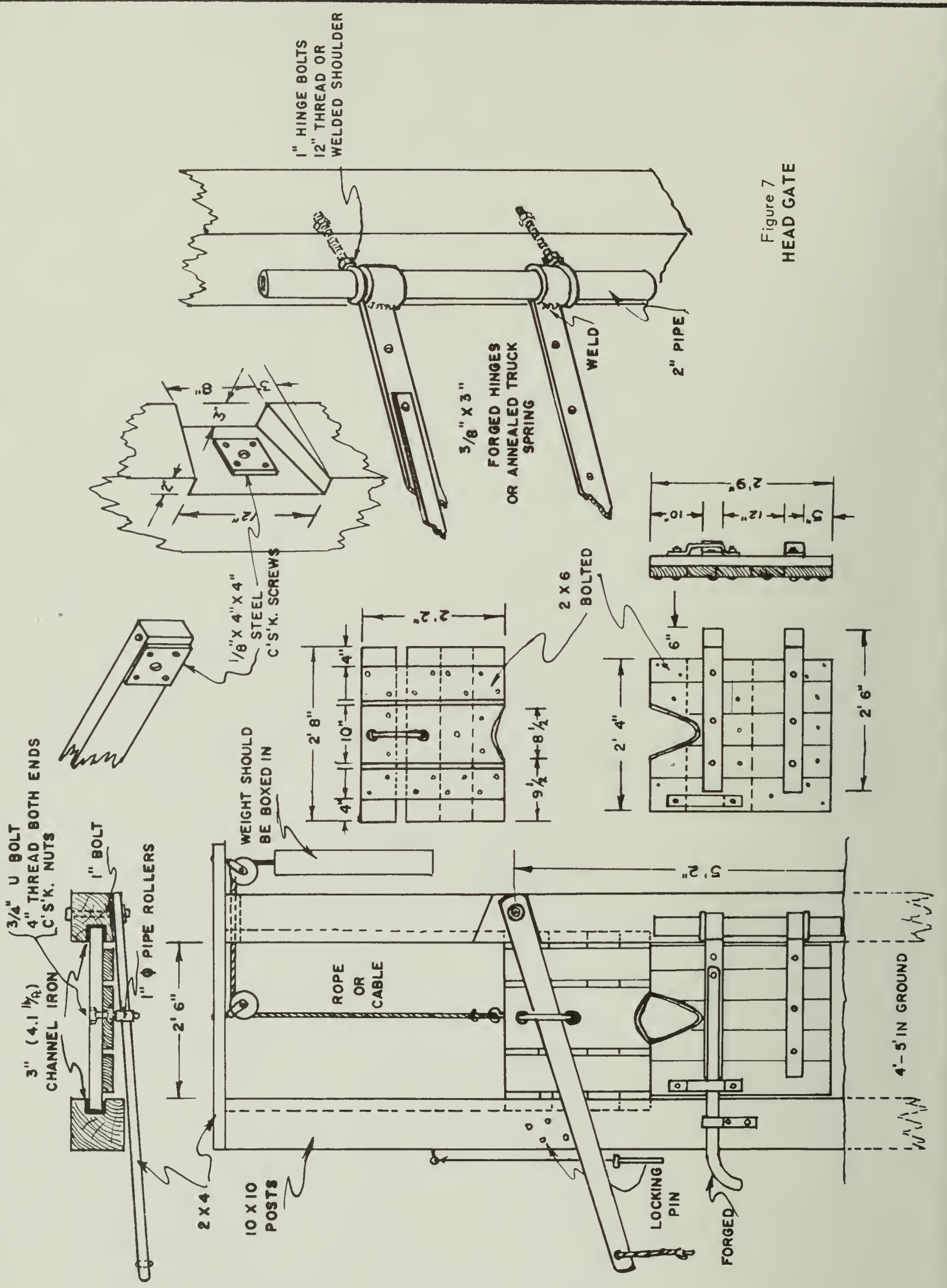




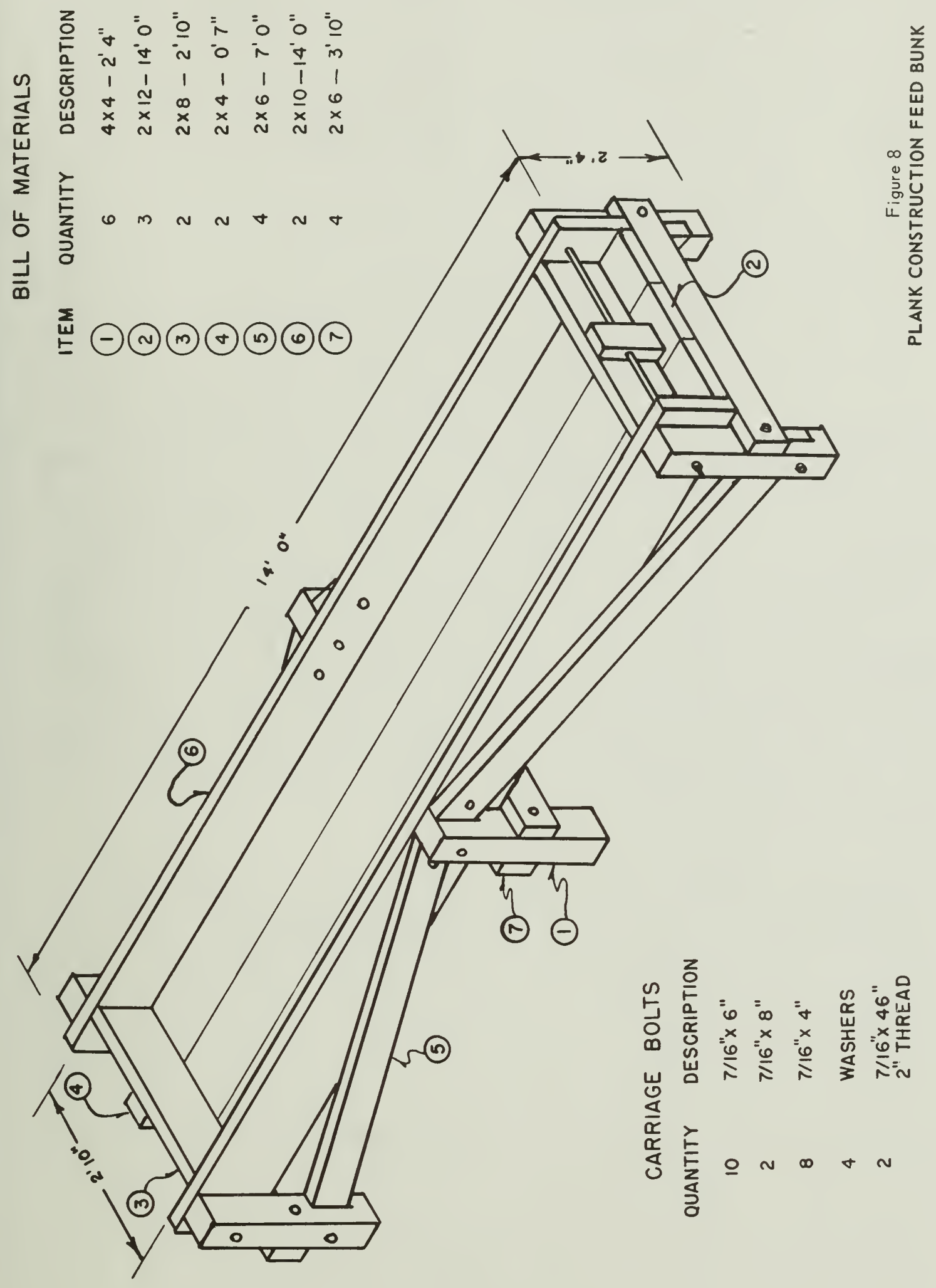




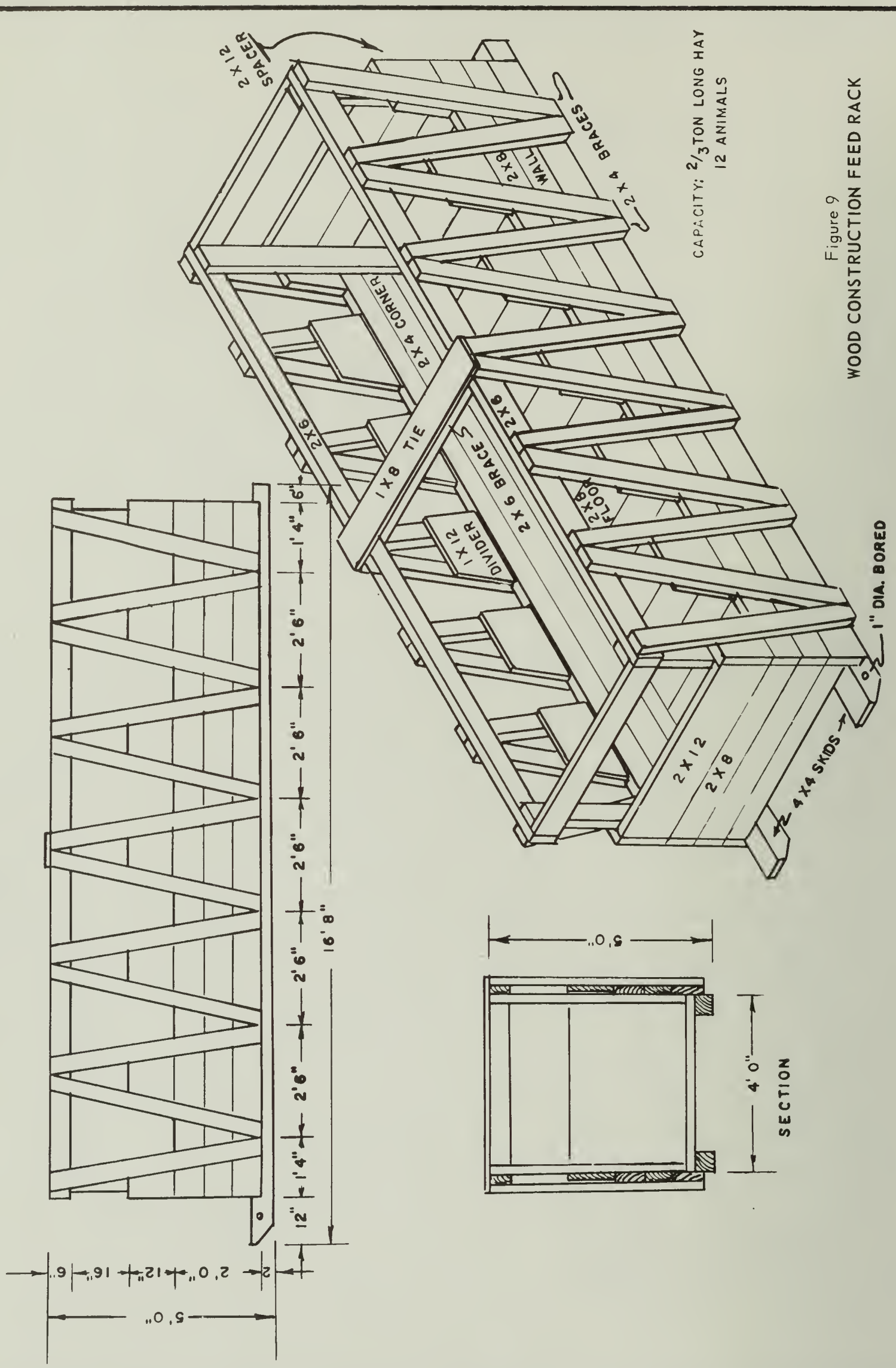


In general, the feed bunks should be 24 inches high for calves ( 600 pounds or less), and 30 inches high for older cattle (over 600 pounds). Have them about 8 inches deep for calves and 8 to 10 inches deep for older cattle. Make the bunks 24 to 30 inches wide for feeding from one side, and about 36 inches wide for feeding from both sides.

With grain and other concentrates, for calves and older cattle allow 18 to 24 inches and 20 to 30 inches of space respectively for each animal when they are hand-fed. When the animals are self-fed, allow 6 to 9 inches and 8 to 12 inches of space per head for calves and older cattle respectively.

The feed rack illustrated in Figure 9 is designed to hold 2/3 ton of long hay, enough to last twelve animals 5 to 6 days if fed 20 pounds per head per day. This design is good because the animals are unable to crowd one another out of their places. See also Canada Plan Service, leaflet 2157. Some cattlemen favor the use of combination feed racks for grain and roughage, whereas others choose a rack for hay, and a separate bunk or flat manger for silage and grain.

When liberal grain and other concentrates are being fed, provide 6 to 9 inches of roughage rack space per head for free-choice feeding of dry roughage and 12 to 18 inches for silage. When little or no grain is being fed, 12 inches of space should be provided per head for dry roughage and 24 inches for silage.

On irrigated pastures it is sometimes desirable to feed molasses, or coarse grains, or both. A portable feed bunk does the job well, but it should have plenty of weight and width to keep it from tipping. Good dimensions are 12 feet long, 2 feet high, and 30 inches wide. Make the legs of $4 \times 4$ inch material, and the main part of the bunk of 24-gauge galvanized iron. Build it in the shape of a half circle and support it at the sides and bottom with $2 \times 10$ inch planking. This method of construction provides a smooth, easily cleaned, and extremely tight bunk.

\section{SELF-FEEDERS}

Self-feeding of concentrates and chopped hay is practical and a labor saver, especially in range feeding or on irrigated pastures. There are many designs for self-feeders. A few are illustrated in this publication to show the construction details. Self-feeders for creep feeding calves are usually placed near the water or other places where cattle congregate. The type illustrated in Figure 10 requires a fence around it with openings 18 inches wide to permit the calves to enter. Another type (Figure 11) has a large roof overhead and does not require any additional fencing. Calves are usually allowed access to creep feeders while they are nursing their mothers. This practice is followed when the feed supply is limited, when the calves are to be fattened at an early age and marketed at about 900 pounds, or when the dams are very young and producing insufficient milk for their calves. The portable self-feeder illustrated in Figure 12 has a door opening at each end to facilitate loading. It holds about 150 bushels of grain. This type is also used to feed other concentrates such as dried grains and linseed meal. The linseed meal is sometimes mixed with salt to control corsumption by the livestock. 


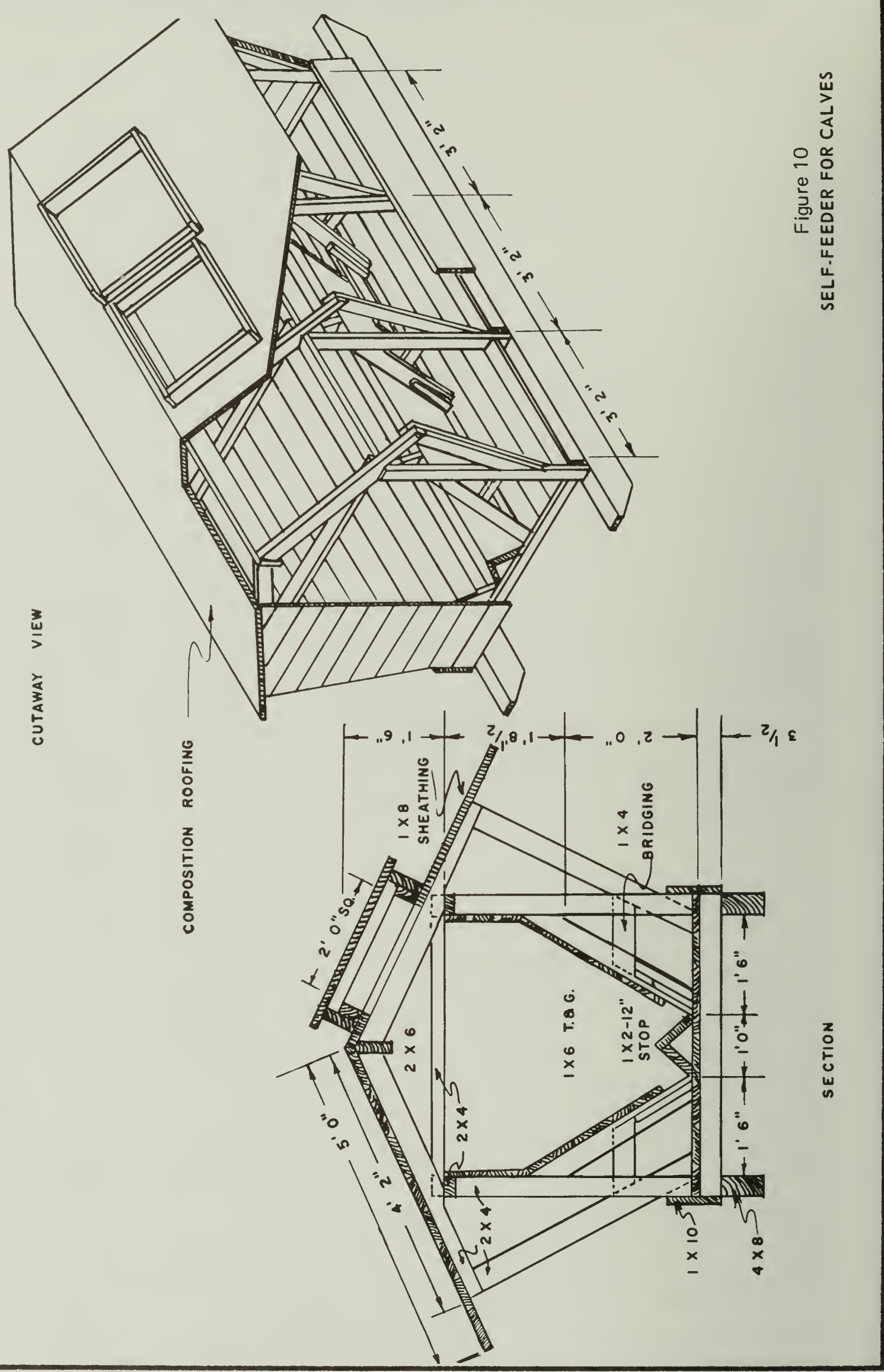



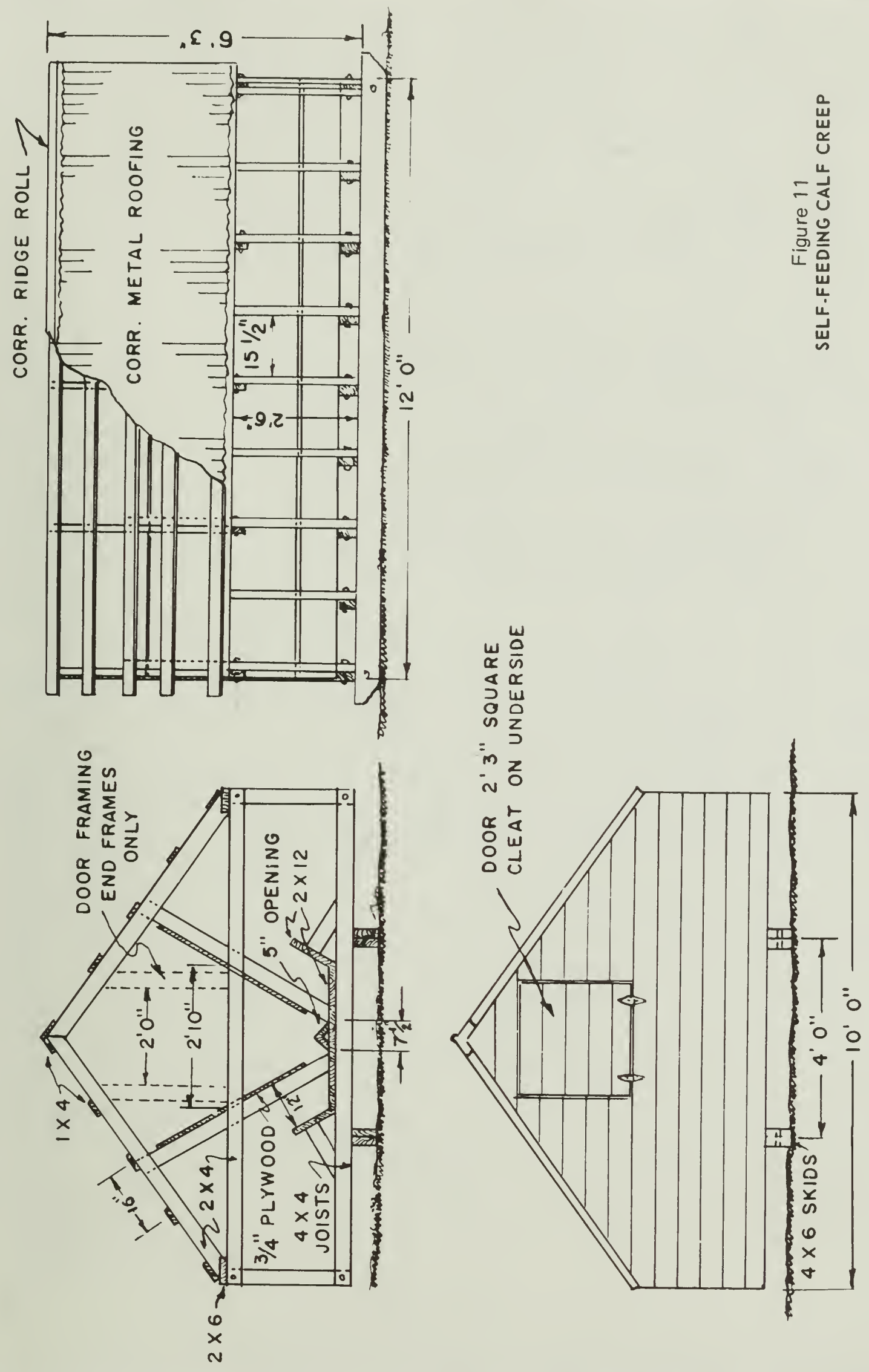


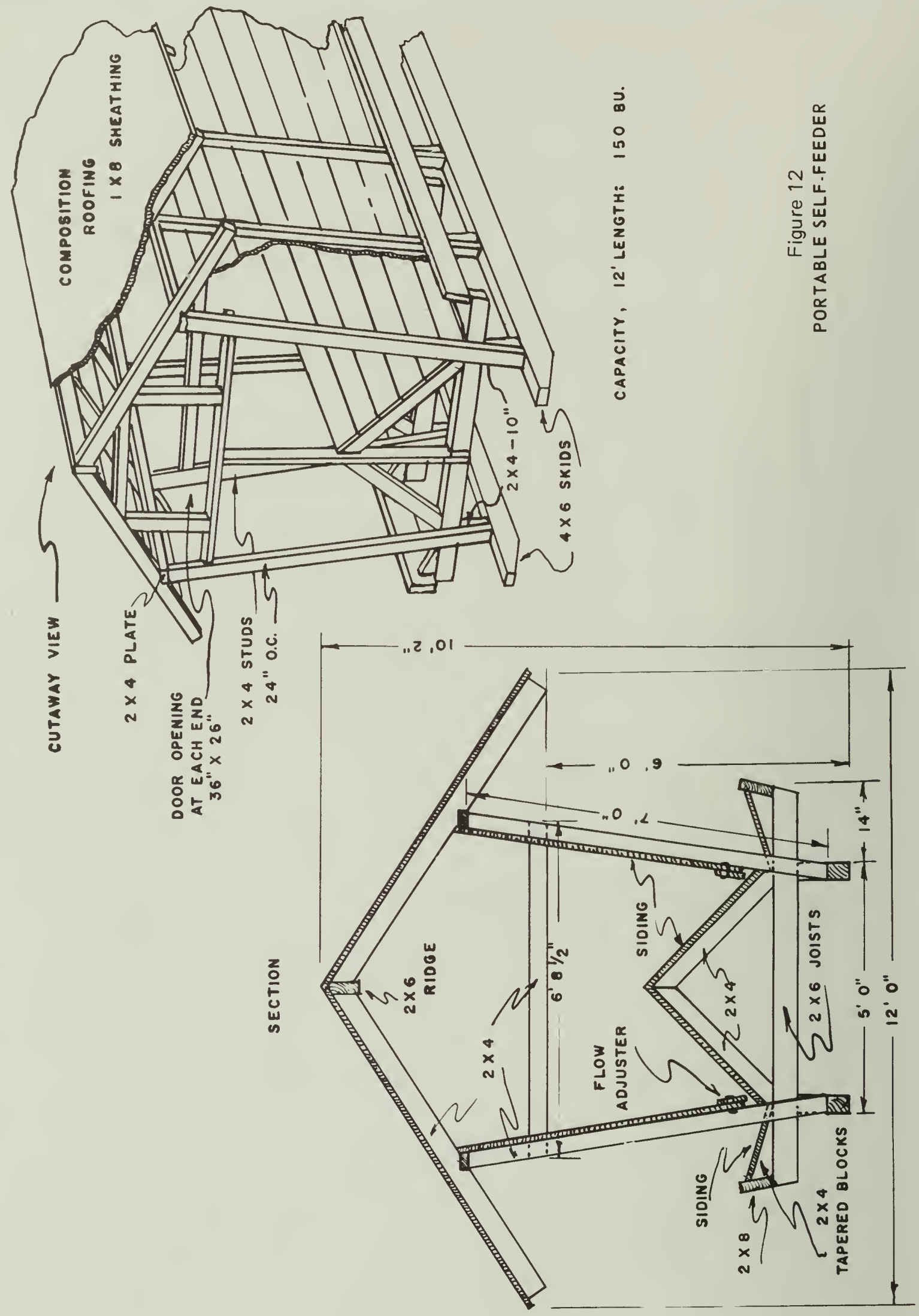


For paved lots, provide 50 to 100 square feet of outside lot space per head. Allow a slope of $1 / 4$ to $1 / 2$ inch per foot. For dirt lots, allow 150 to 200 square feet per head, and a slope of $1 / 2$ inch or more per foot, depending on the type of soil. Provide a paved area of at least 10 feet around watering troughs, feed bunks, and forage racks.

A total of 20 pounds of wood chips or shavings per head per day are adequate for bedding. Manure or soil mounds also provide cattle with a drier resting area. Plan to clean out your feedlots once in the spring.

\section{FENCES AND GATES}

Fences There are several kinds of fences. Boundary fences prevent animals from trespassing on neighboring property, whereas drift fences keep livestock from getting off the range or on to it, and confine herds to specific elevations. Some fences merely divide the range so that each part is used properly. Pasture fences provide facilities for easy handling of livestock on the range, such as enclosures for saddle and pack animals. They also hold livestock temporarily during roundups, or other times, or reserve feed for special uses, such as for milk cows. Areas where erosion is being controlled, or small areas that have heavy stands of poisonous plants, are fenced to keep livestock away.

Figure 13 shows a good wire fence and the spacings required. It also illustrates the bracing for the corners and gate openings. Where it is impractical to set posts in the ground, rock jacks are used to support the fence posts (Figure 14). There are several types of pole fences used (Figure 15), the log and block, the snake, and the Russell fences being the common types in the timbered areas. Seasoned lodgepole pine free of limbs and knots is the best construction material. The bark must be peeled or stripped to prevent undue decay. Some of the poles may be split into "rails."

Gates A ranch needs many gates. The fence gate illustrated in Figure 16 is an excellent type but it must be properly built. Gates that are to swing must not sag or warp easily. To be efficient they must open easily and stay closed when shut. The rugged corral gate shown in Figure 17 swings freely.

Cattle guard Where fences cross roads that are used often, cattle guards should be installed. Permanent guards can be constructed of planks, of concrete and wood, or of concrete and steel. Those illustrated in Figures 18 and 19 give some idea of typical construction. A pit dug under the full extent of the cattle guard provides room to clean out the debris occasionally, because the guard fills up after a time. A portable cattle guard made of a bedspring can be used on irrigated pastures or placed in gate position where a gate has to be left open for a long time. As Figure 20 shows, it is all-metal construction.

\section{WATERING FACILITIES}

Adequate stock-watering facilities are very important on a cattle range. They must provide for even distribution of livestock over the range, secure utilization of 
areas not usable because of a lack of water, and improve the quality of water for livestock. Cattle need as much as 10 gallons of good clean water every day, and to obtain it they should not have to travel more than half a mile in rough country, or 2 miles over level land. Water is provided by springs, wells with windmills or pumps, and reservoirs. Table 1 gives the number of pounds of water consumed by cattle and sheep per day.

Pipes and troughs are almost always used with springs and wells. Probably the most desirable trough, especially in feedlots, is the round concrete type. But it is rather expensive, and sometimes cracks are made in it by frost. In many places rectangular cement watering troughs with sloping sides have proved successful. The sloping sides tend to prevent frost damage if the trough is left full of water. Two types of watering troughs are illustrated in Figures 21 and 22. Troughs should be placed close to the well on good firm well-drained ground. Some provisions such as a pole across the top may be used to keep stock out of the troughs. Algae may be kept from growing in water tanks and troughs by the use of copper sulfate. This salt is harmless to livestock, yet as little as $1 \mathrm{ppm}$ prevents algal growth. Since the salt dissolves slowly, a few crystals may be placed in a bottle fitted with a cork having a small slot cut in the side. This bottle is placed in the trough and the copper sulfate allowed to pass slowly from the bottle. Provide a flat board to prevent birds from drowning and decomposing in the trough, and a piece of canvas tied on the side and hanging in the water so that rodents that fall in can escape.

Round galvanized steel tanks do not require as much attention as wooden troughs that can be damaged by cattle crowding around them. But they must be drained in the fall to prevent damage by frost. Allow 1 linear foot of open water tank space for each 10 head of cattle, or provide one automatic watering bowl for each 25 head of cattle.

Livestock will not drink enough water during the winter if they have to drink it ice cold. Any of the stock-watering heaters now on the market may be used to heat the water. Satisfactory water temperature is $40^{\circ}$ to $80^{\circ} \mathrm{F}$.

\section{SILOS}

Silage is a valuable feed for beef cattle in winter and for fattening cattle for market, especially in areas where legume hays are not abundant. More and more farmers are putting their first cutting of hay into silos, and in this way they avoid the possibility of having the first crop ruined by inclement weather. There are two types of silos: one, aboveground, including tower and surface silos, and the other, the trench type. The Research Station, Kamloops, B.C., has developed a very simple aboveground silo. The walls are movable (Figure 23) and can be used as many times as necessary by disconnecting the cross tie cables and pulling them up with a tractor.

\section{VOLUME AND WEIGHT OF HAY AND SILAGE}

To find the number of tons of hay in a stack, first find the volume of the stack by using one of the following formulas.*

\footnotetext{
*From the United States Department of Agriculture Leaflet 72, 1931.
} 


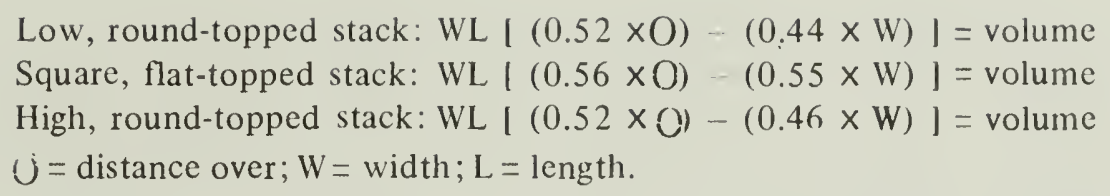

Example: to determine the volume for a rectangular stack of the high, roundtopped type that is 45 feet over, 20 feet wide, and 50 feet long:

Volume $=(20 \times 50) \times[(0.52 \times 45)-(0.46 \times 20)]$

$=1000 \times(23.40-9.20)$

$=14,200$ cubic feet in the stack.

Since about 590 cubic feet of loose hay weigh 1 ton, 14,200 cubic feet weigh $14,200 / 590$, or about 2.4 tons.

Table 2 gives the approximate volume per ton of other hay, and of silage.

One ton of shavings, baled and slightly moist, occupies about 100 cubic feet; and 1 ton of wheat, weighing 60 pounds per bushel, occupies about 42 cubic feet.

Table 3 gives the capacity of tower silos at the time the silos are filled and without refilling. After 2 to 3 weeks the capacity of a silo is increased by 25 to 30 percent. Silage weight varies from 35 to 45 pounds per cubic foot, depending on packing and height of silo.

Table 4 gives the capacity of trench and surface silos, based on 35 pounds per cubic foot. To determine the total length of the silo, add 20 feet to the length of the main section to allow for the 10 -foot slope at each end.

\section{FARM SCALES}

Farm scales are useful in recording gains of livestock and for weighing roughage and grains. They should be located so that cattle can be worked in adjoining corrals without having to pass over them. The scales should have some housing or shelter over them.

\section{DEHORNING, BRANDING, AND CASTRATION}

Equipment for dehorning cattle includes various types of saws, mechanical dehorners, and dehorning tubes. Commercial preparations of caustic soda or potash are also used on young animals to prevent the growth of horns.

Permanent marking of cattle for identification is accomplished by branding, either by use of a hot iron, or a cold iron dipped in branding fluid, or tattooing. Open letters such as $\mathrm{O}, \mathrm{C}, \mathrm{D}$, and $\mathrm{P}$ can be made distinctly with a stamping iron. A running iron is a plain hook; letters such as $\mathrm{A}, \mathrm{M}, \mathrm{N}, \mathrm{W}$, and $\mathrm{X}$ can usually be made with it by applying it the required number of times to complete the letter.

Castration is done with a knife or mechanical pincers. For carrying out the operation, the animal may be held by roping and throwing, or by using a squeeze. The squeeze is preferred because it makes injury less likely, gives greater ease of handling, and saves labor. For calves, use of a commercially built branding table saves time and labor. 
Table 1. Water consumption of cattle and sheep

\begin{tabular}{|c|c|c|}
\hline Animal & Condition(s) & $\begin{array}{l}\text { Water consumption } \\
\text { (pounds per day)* }\end{array}$ \\
\hline \multicolumn{3}{|l|}{ Cattle } \\
\hline \multirow[t]{7}{*}{ Holstein calves } & $\begin{array}{l}\text { On liquid milk, or on } \\
\text { dried milk and water }\end{array}$ & \\
\hline & 4 weeks old & $10-12$ \\
\hline & 8 weeks old & 13 \\
\hline & 12 weeks old & $18-20$ \\
\hline & 16 weeks old & $25-28$ \\
\hline & 20 weeks old & $32-36$ \\
\hline & 26 weeks old & $33-48$ \\
\hline Dairy heifers & Pregnant & $60-70$ \\
\hline \multirow[t]{2}{*}{ Steers } & On maintenance ration & 35 \\
\hline & Fattening & 70 \\
\hline Range cattle & & $35-70$ \\
\hline Jersey cows & $\begin{array}{l}\text { On milk production } \\
5-30 \text { pounds per day }\end{array}$ & $60-102$ \\
\hline \multirow[t]{2}{*}{ Holstein cows } & $\begin{array}{l}\text { On milk production } \\
\begin{array}{r}20-50 \text { pounds per day } \\
80 \text { pounds per day }\end{array}\end{array}$ & $\begin{array}{r}80-102 \\
190\end{array}$ \\
\hline & Dry & 90 \\
\hline \multirow[t]{4}{*}{ Sheep } & On range or dry pasture & $5-13$ \\
\hline & On range (salty feeds) & 17 \\
\hline & $\begin{array}{l}\text { On rations of hay and grain, } \\
\text { or hay, roots, and grain }\end{array}$ & $0.3-6$ \\
\hline & On good irrigated pasture & $0.1-0.3$ \\
\hline
\end{tabular}

*One gallon of water weighs 10 pounds.

Table 2. Storage space requirements for hay and silage

\begin{tabular}{lc}
\hline \multicolumn{1}{c}{ Material } & $\begin{array}{c}\text { Approximate volume } \\
\text { (cubic feet) per ton }\end{array}$ \\
\hline Hay: loose in shallow mows & $510-550$ \\
loose in deep mows & $440-500$ \\
baled in tight bales & 100 \\
baled in loose bales & 130 \\
baled in small loose bales & 200 \\
chopped extra long, 4 to 5 inches & 500 \\
chopped long, 2 to 3 inches & $250-300$ \\
Silage: Shallow silo, under 25 feet & 67 \\
high silo & 40 \\
trench silo (packed by tractor) & 40 \\
Straw: loose & 500 \\
baled & 170 \\
\hline
\end{tabular}




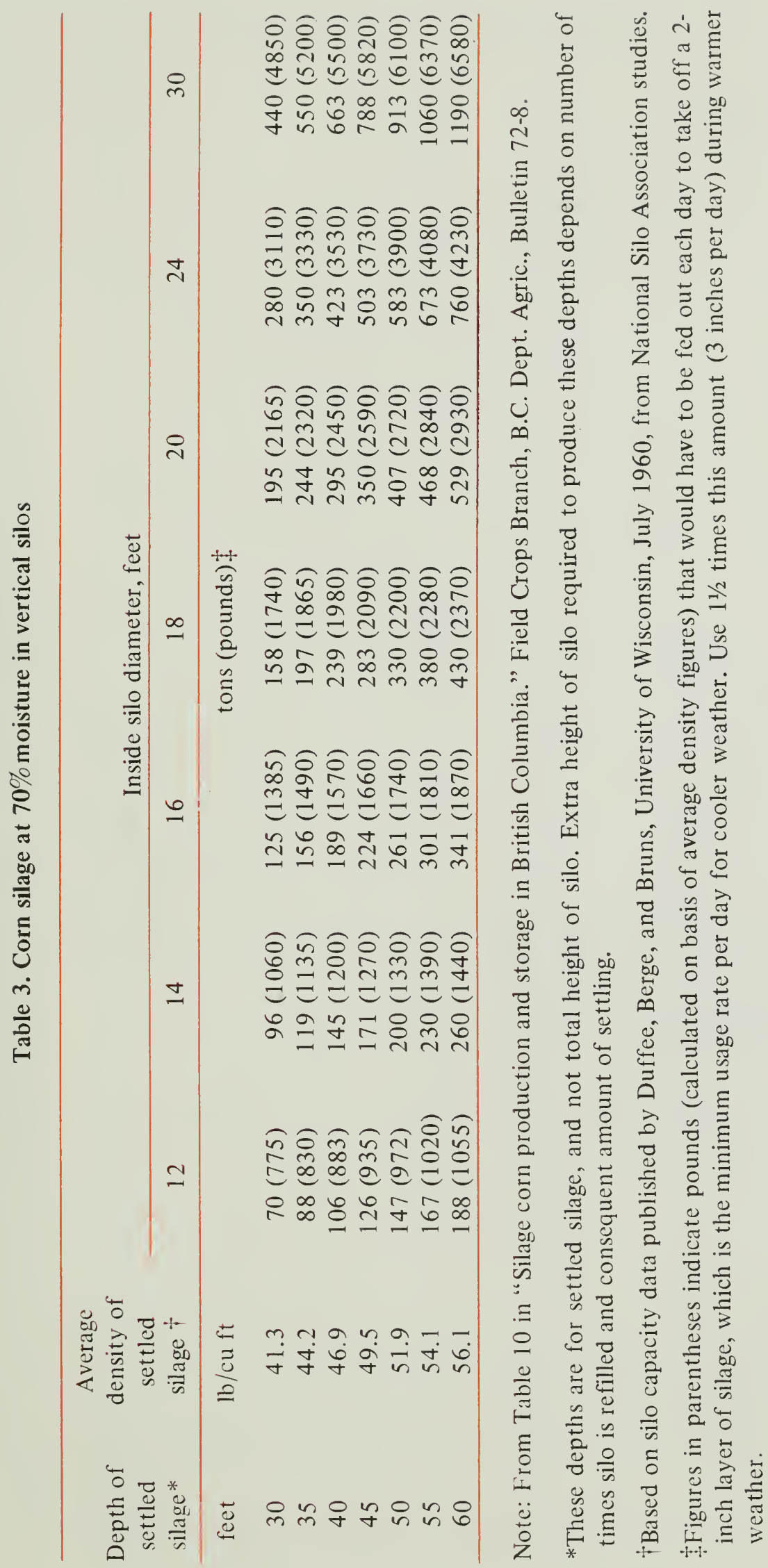


Table 4. Corn silage at $70 \%$ moisture in horizontal silos

\begin{tabular}{|c|c|c|c|c|}
\hline \multicolumn{2}{|c|}{ Silo width, feet } & \multirow{2}{*}{$\begin{array}{l}\text { Depth of } \\
\text { settled } \\
\text { silage, } \\
\text { feet }\end{array}$} & \multirow{2}{*}{$\begin{array}{l}\text { Silage per } \\
\text { lineal foot } \\
\text { of silo, } † \\
\text { tons }\end{array}$} & \multirow{2}{*}{$\begin{array}{c}\text { Silage in } \\
3 \text {-inch } \\
\text { vertical slice, }+ \\
\text { pounds }\end{array}$} \\
\hline Bottom & Top* & & & \\
\hline \multirow[t]{2}{*}{12} & 14 & 6 & 1.37 & 623 \\
\hline & & 8 & 1.82 & 910 \\
\hline \multirow[t]{2}{*}{14} & 16 & 6 & 1.58 & 788 \\
\hline & & 8 & 2.10 & 1050 \\
\hline \multirow[t]{2}{*}{14} & 18 & 10 & 2.80 & 1400 \\
\hline & & 12 & 3.36 & 1680 \\
\hline \multirow[t]{2}{*}{16} & 18 & 6 & 1.79 & 893 \\
\hline & & 8 & 2.38 & 1190 \\
\hline \multirow[t]{2}{*}{16} & 20 & 10 & 2.15 & 1575 \\
\hline & & 12 & 3.78 & 1890 \\
\hline \multirow[t]{2}{*}{20} & 22 & 6 & 2.21 & 1103 \\
\hline & & 8 & 2.94 & 1469 \\
\hline \multirow[t]{2}{*}{20} & 24 & 10 & 3.90 & 1950 \\
\hline & & 12 & 4.62 & 2310 \\
\hline \multirow[t]{2}{*}{24} & 26 & 6 & 2.63 & 1313 \\
\hline & & 8 & 3.50 & 1750 \\
\hline \multirow[t]{2}{*}{24} & 28 & 10 & 4.55 & 2275 \\
\hline & & 12 & 5.46 & 2730 \\
\hline \multirow[t]{2}{*}{30} & 32 & 6 & 3.26 & 1628 \\
\hline & & 8 & 4.34 & 2170 \\
\hline \multirow[t]{2}{*}{34} & 34 & 10 & 5.60 & 2800 \\
\hline & & 12 & 6.72 & 3360 \\
\hline
\end{tabular}

Note: From Table 11 in "Silage corn production and storage in British Columbia." Field Crops Branch, B.C. Dept. Agric., Bulletin 72-8.

*Measured at top of settled silage.

$\uparrow$ Assumed average density of settled silage $=35 \mathrm{lb}$ per $\mathrm{cu} \mathrm{ft}$.

\$Amount of silage that should be removed from vertical feeding face each day in coole weather (calculated on basis of average density figure). Use $11 / 3$ times this amount (4 inche per day) during warmer weather.

\section{ACKNOWLEDGMENTS}

Acknowledgment is made to the following organizations for the designs of some of the plans: The Canada Plan Service, Ottawa, Ont., for Figures 2 and 3; the Prairie Farm Rehabilitation Administration, Regina, Sask., for Figures 7, 16, 18, and 21; the Department of Public Works, Victoria, B.C., for Figure 19; Colorado State University, Fort Collins, Col., for Figures 1, 10 and 12; and the California Agricultural Experiment Station for Figures 6, 11, and 17.

\section{MORE INFORMATION}

The Canada Plan Service provides copies of its catalogues and plans through provincial departments of agriculture. 


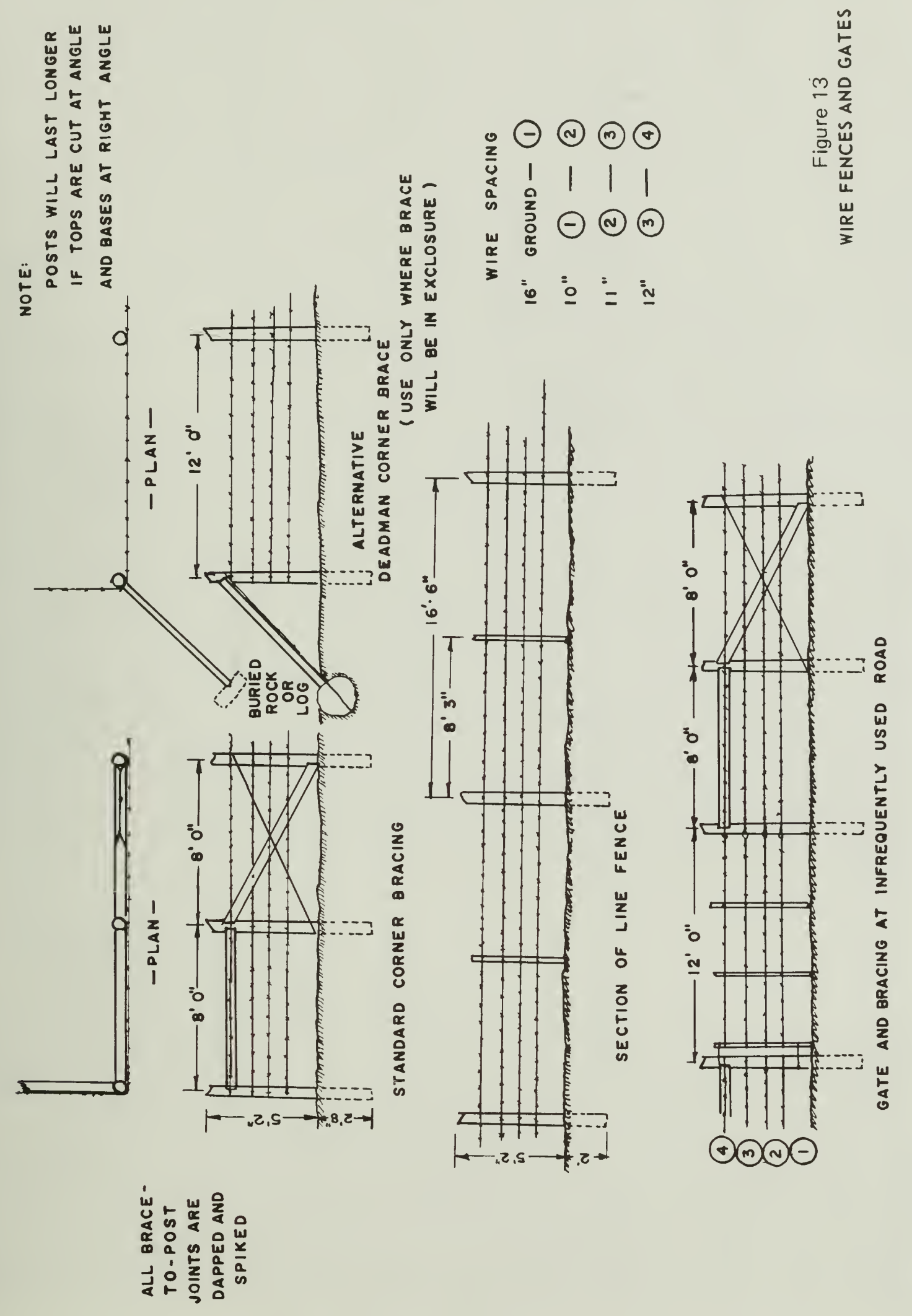




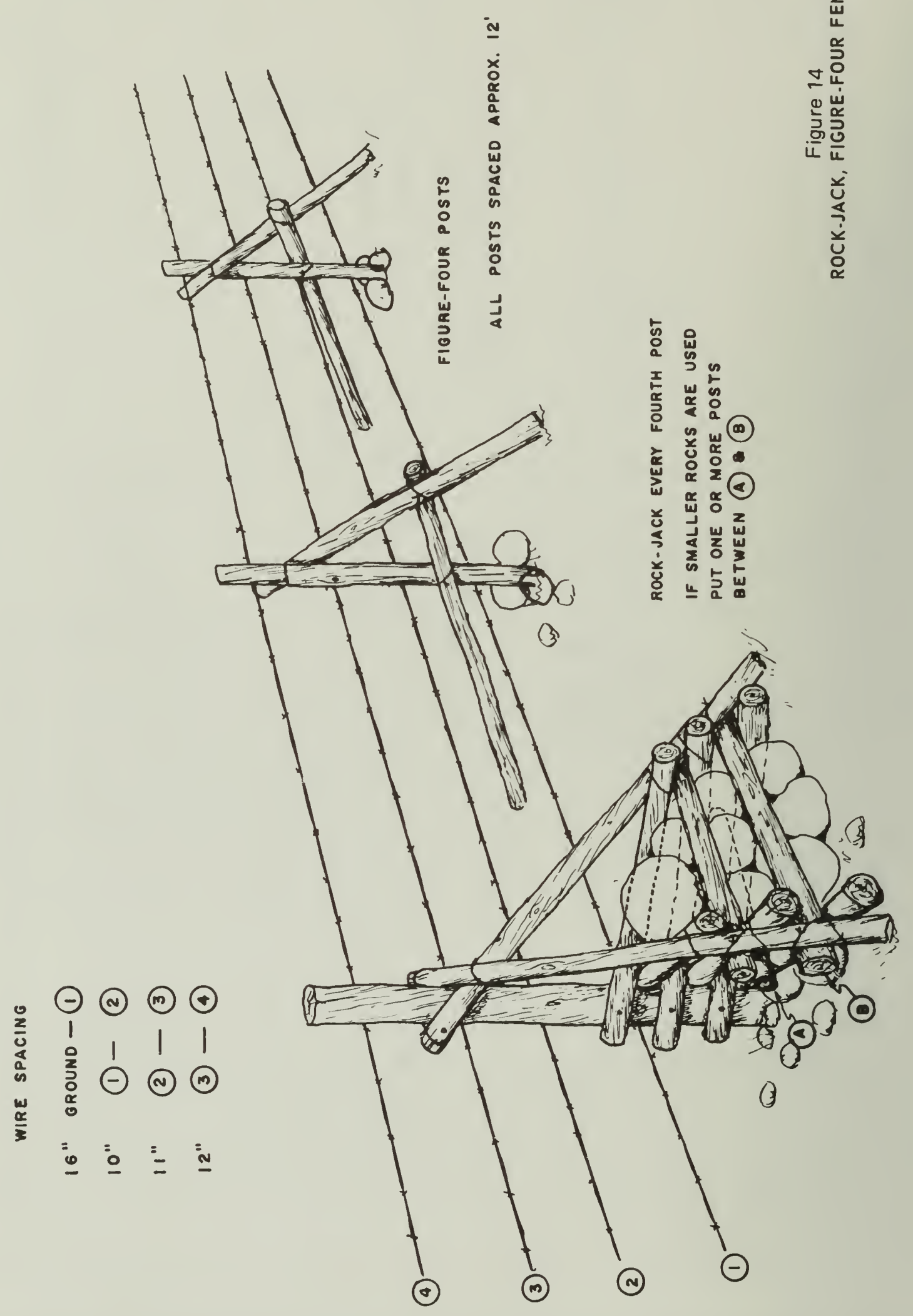



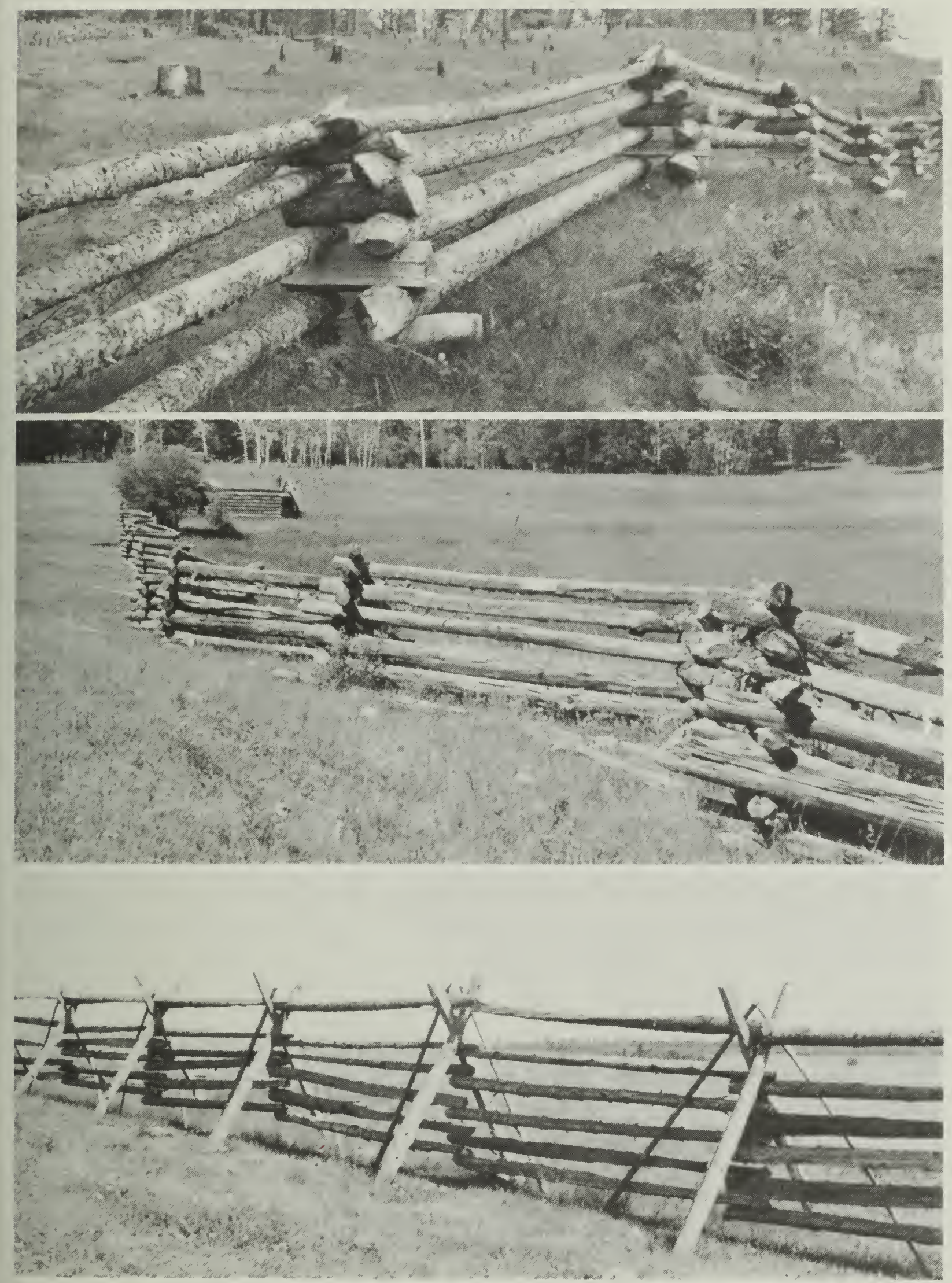

Figure 15. Common pole fences for timbered areas. Upper: a log and block fence. Middle: a snake fence. Lower: a Russell fence. 


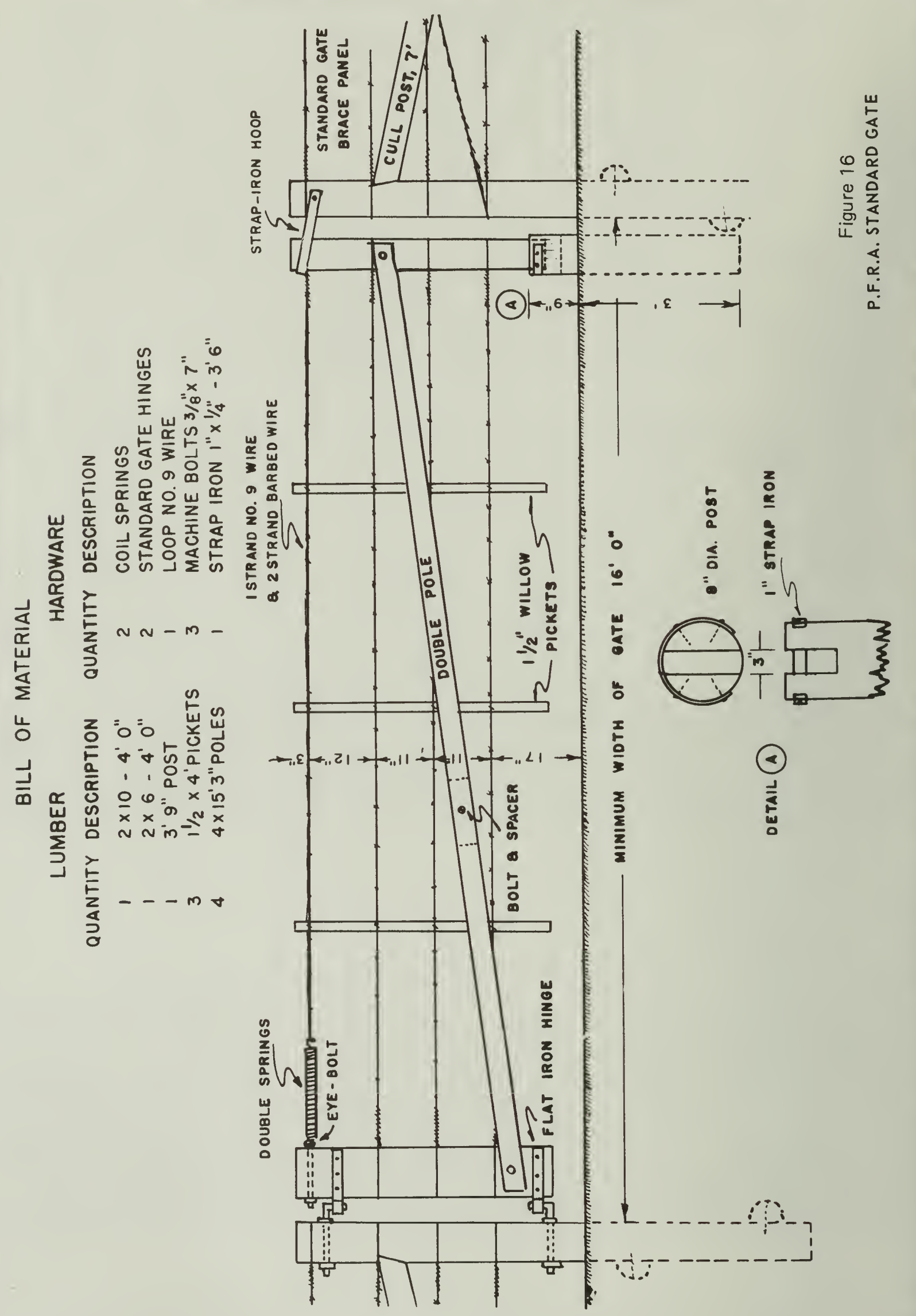




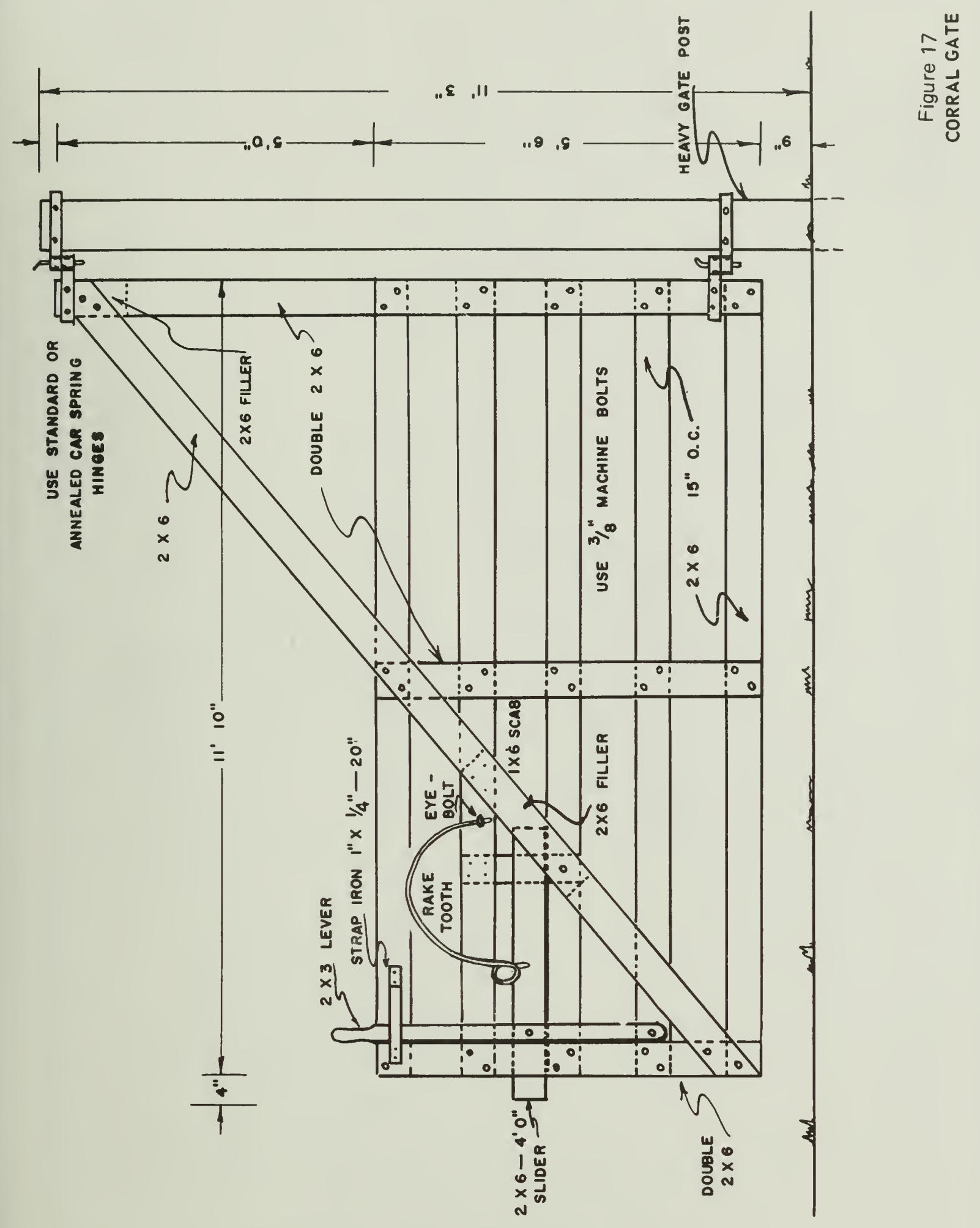




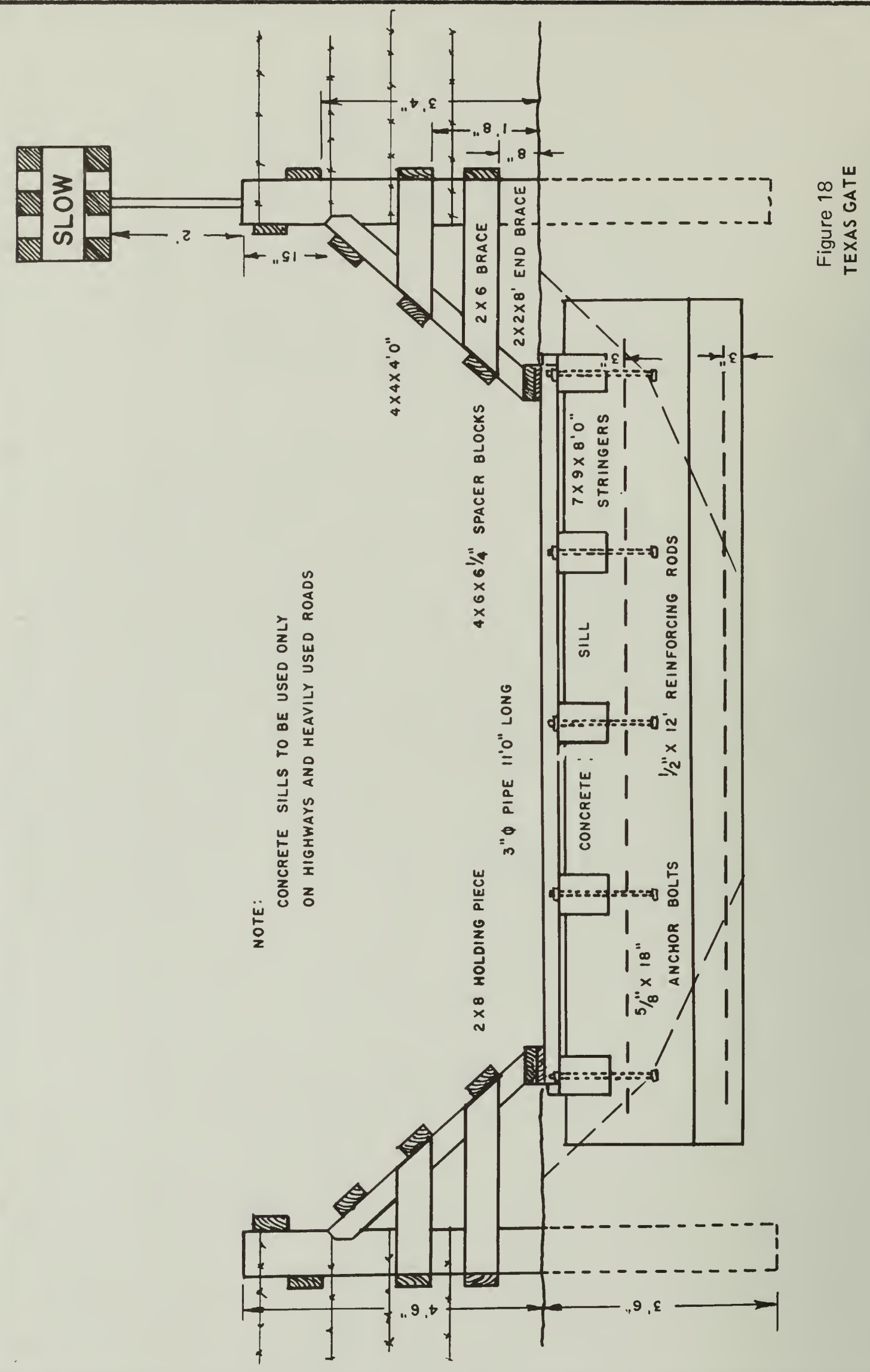




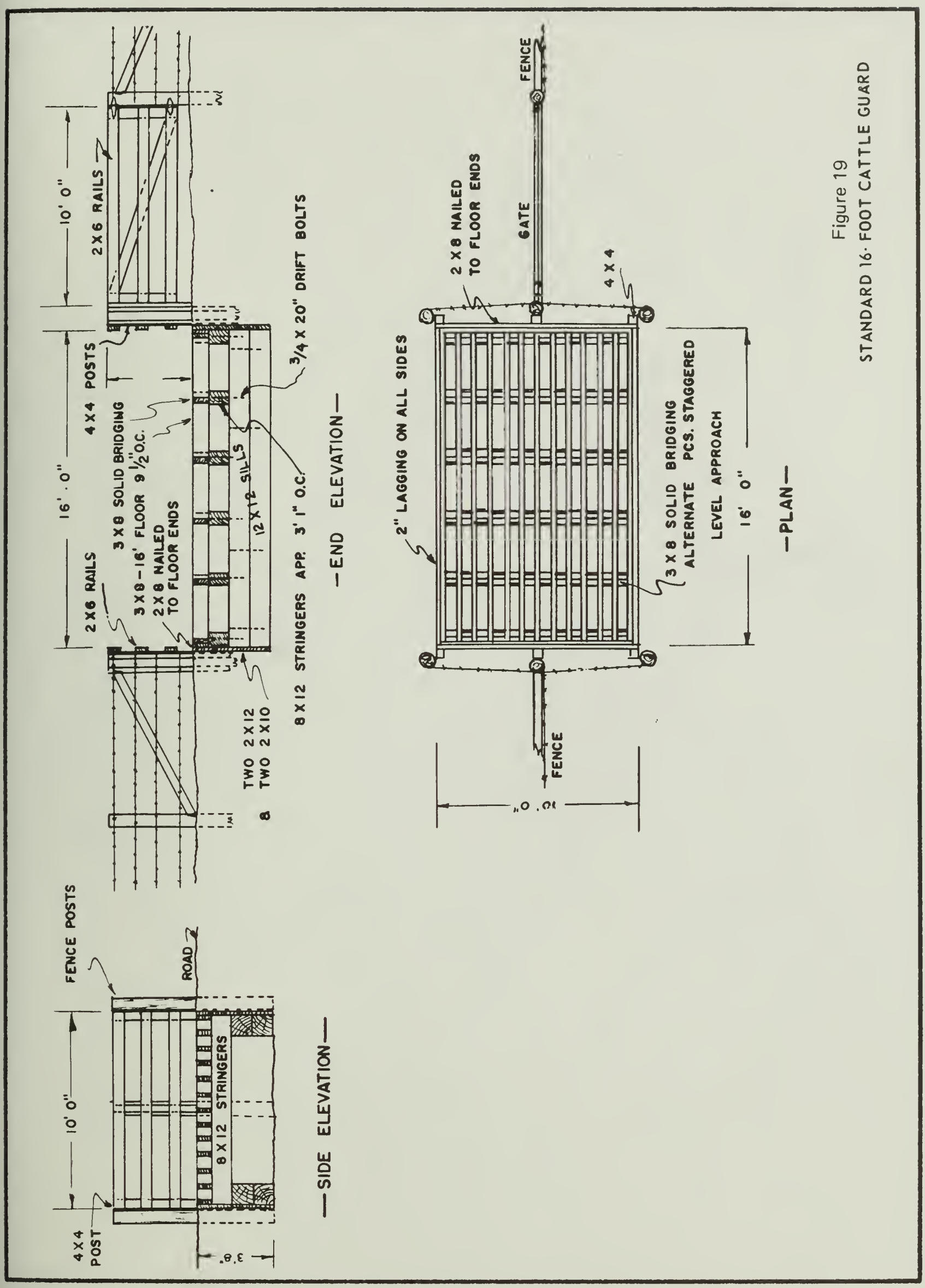




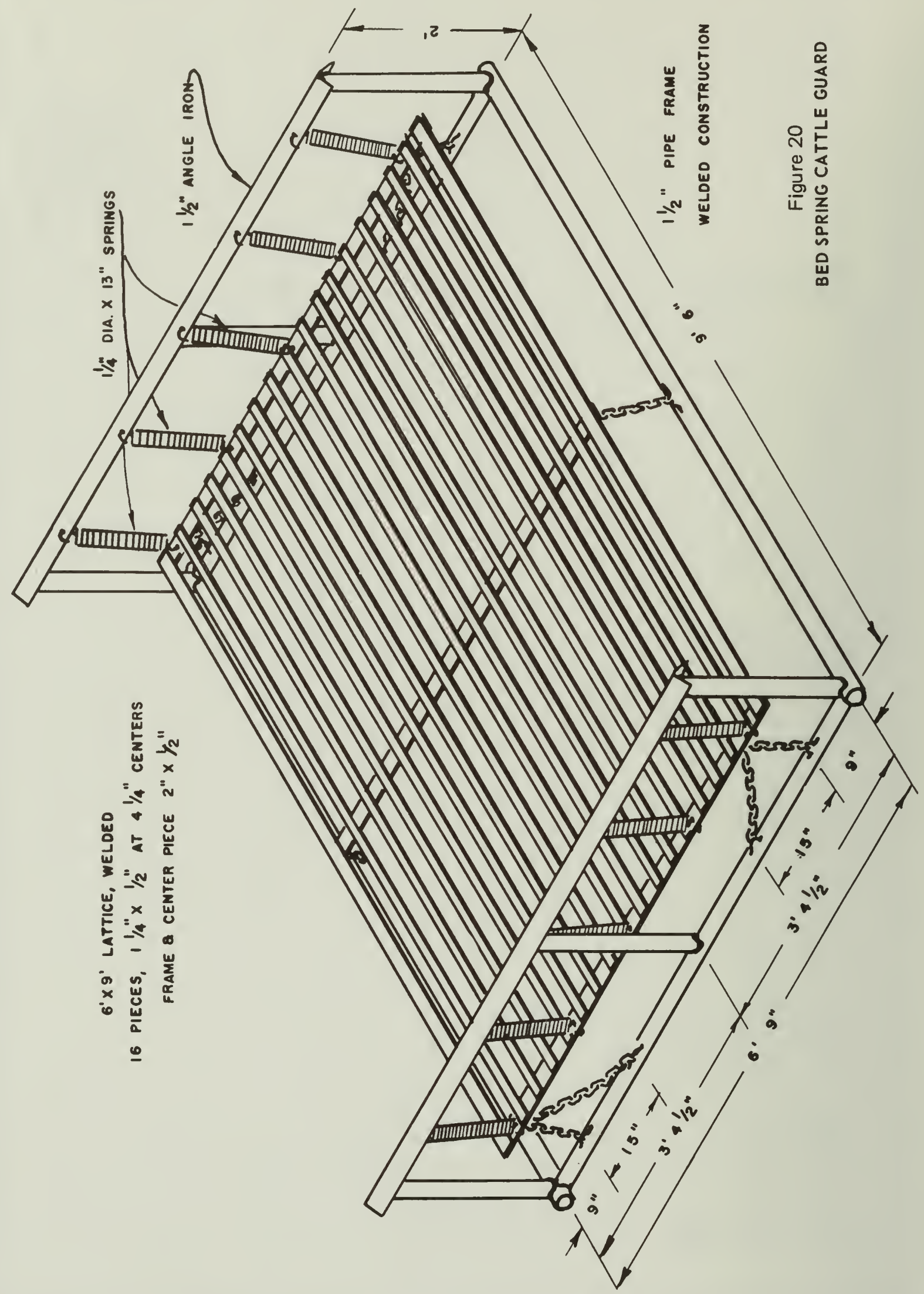




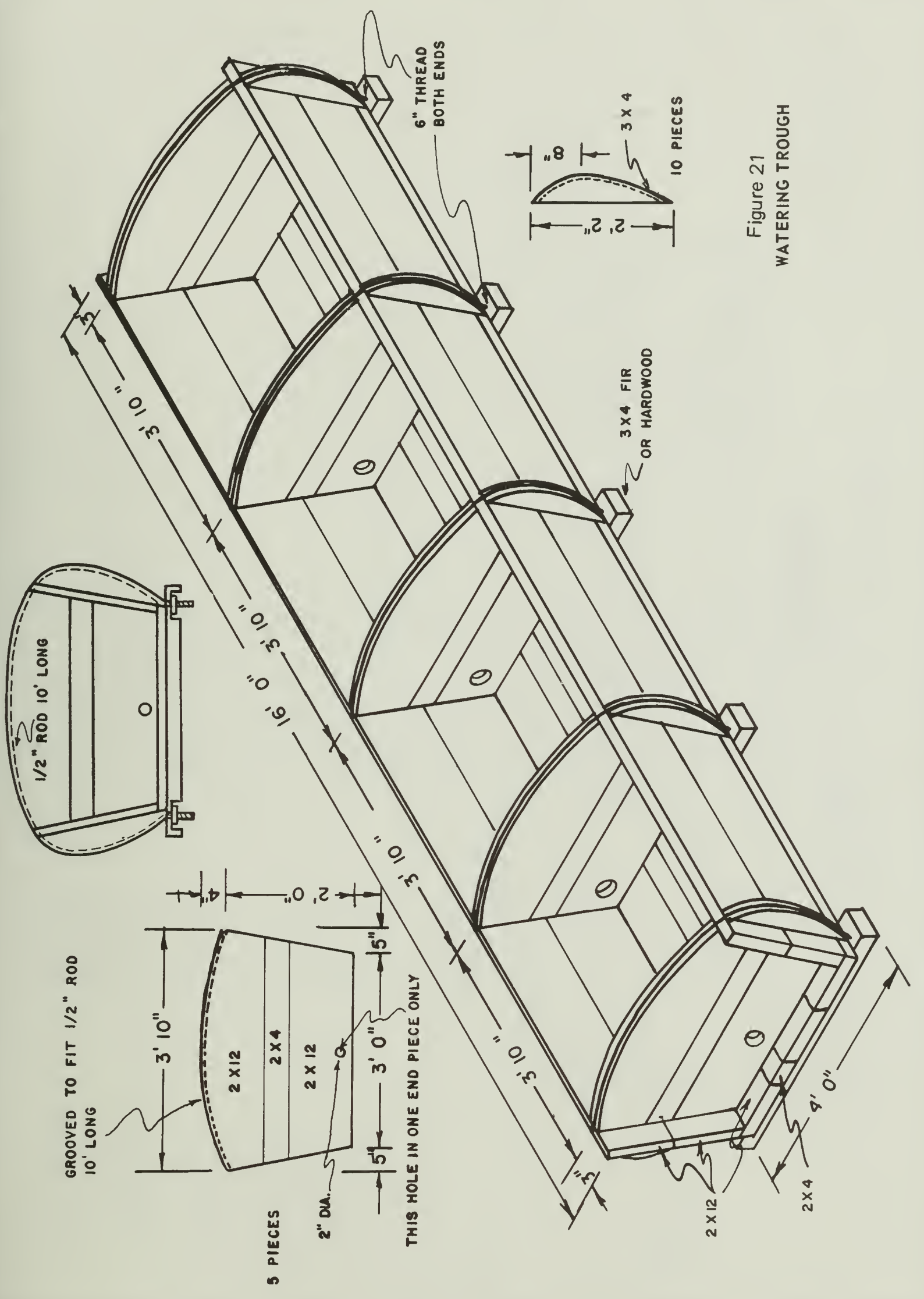



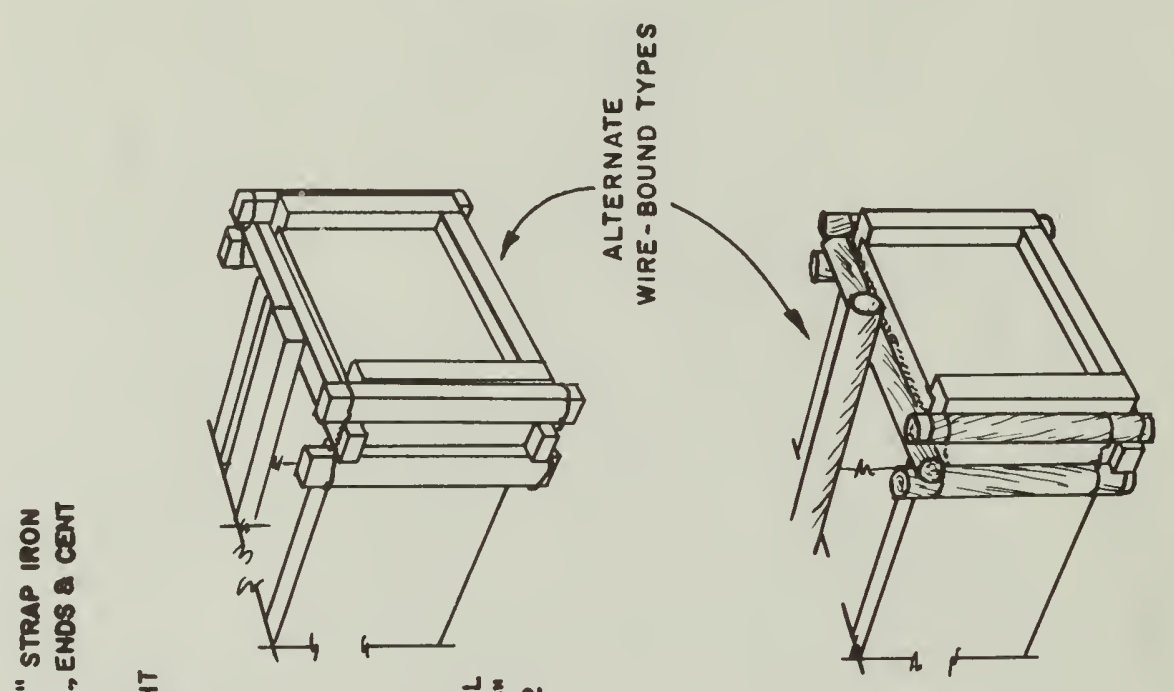

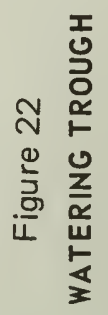

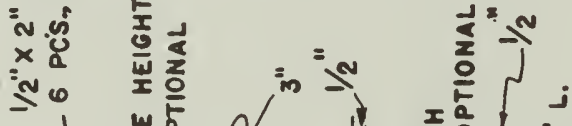

|
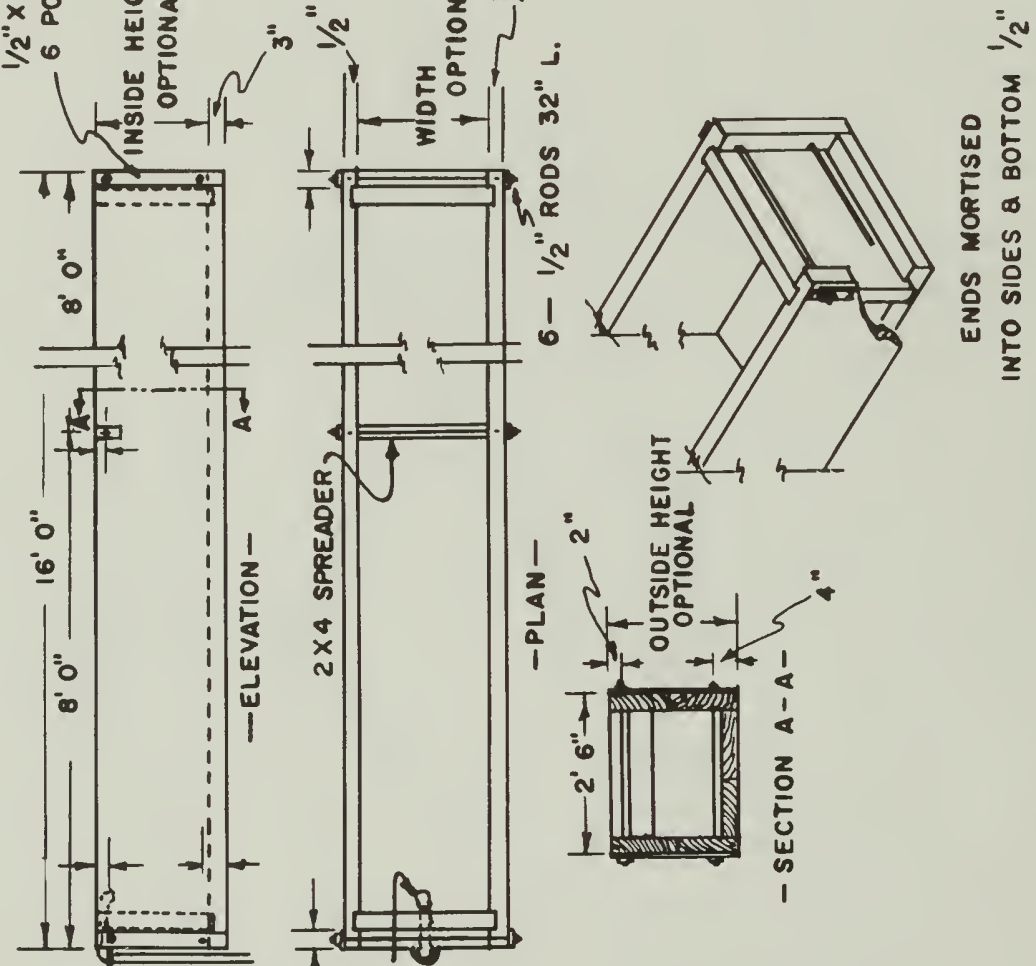

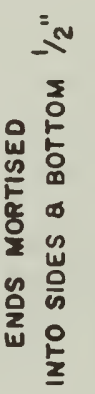

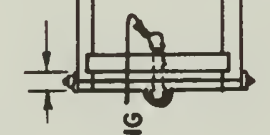

1 


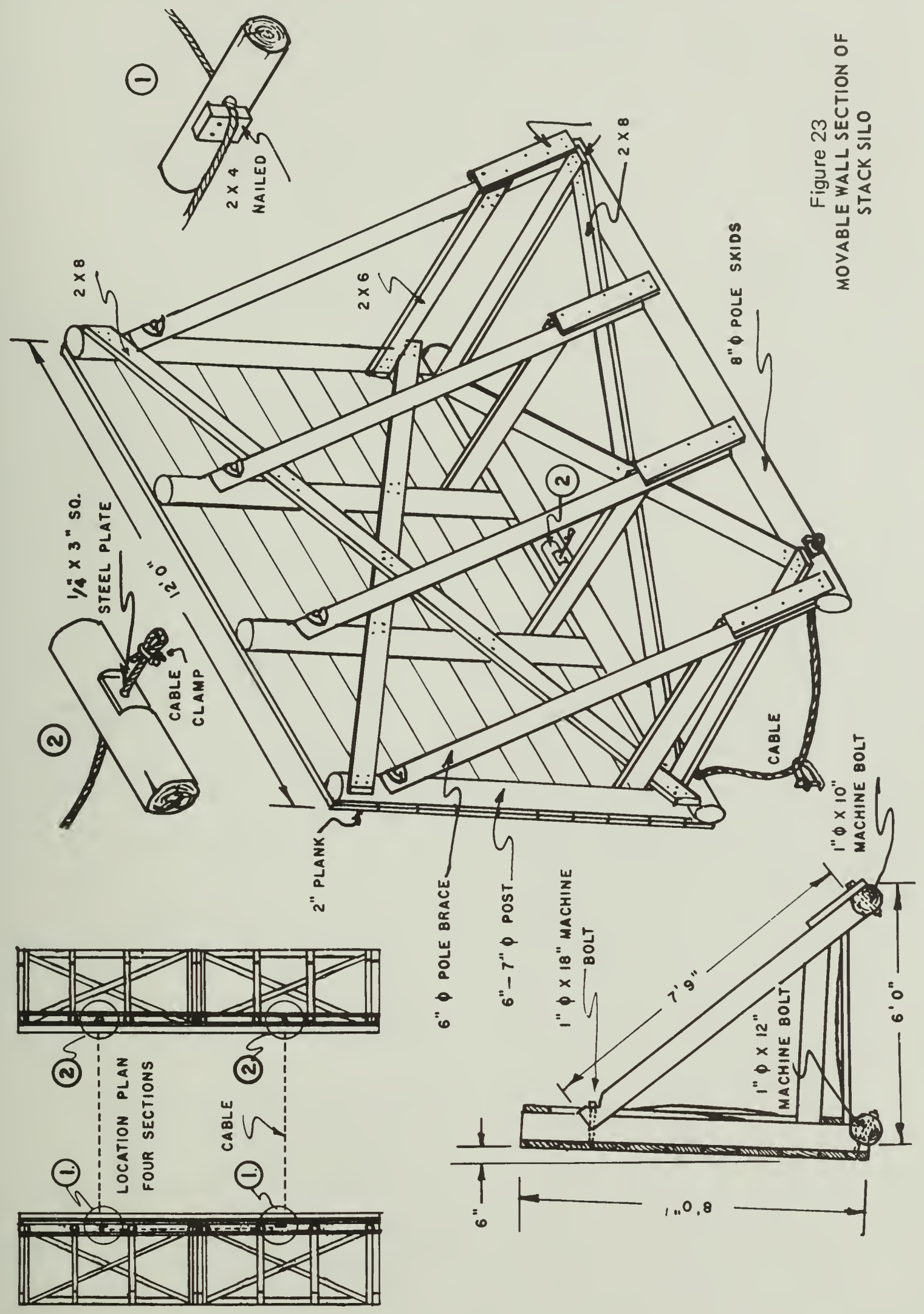


CONVERSION FACTORS FOR METRIC SYSTEM

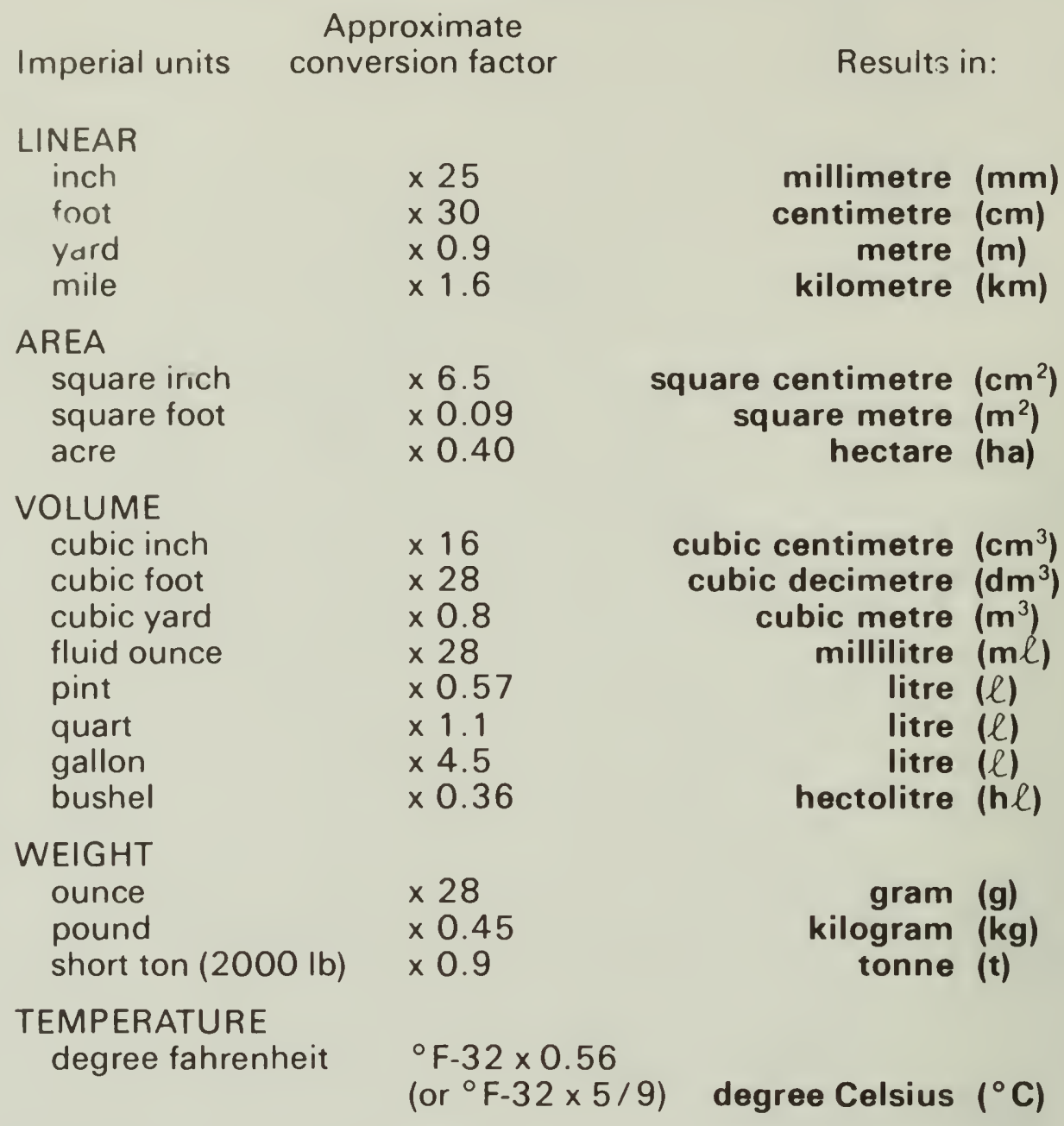

PRESSURE

pounds per square inch $\times 6.9$

kilopascal ( $\mathrm{kPa})$

POWER

horsepower $\quad \times 746$

$\times 0.75 \quad$ kilowatt (kW)

\section{SPEED}

feet per second

miles per hour

$\times 0.30$

$\times 1.6$

metres per second $(\mathrm{m} / \mathrm{s})$

AGRICULTURE

bushels per acre

gallons per acre

quarts per acre

pints per acre

fluid ounces per acre

tons per acre

pounds per acre

ounces per acre

$\times 0.90$

$\times 11.23$

$\times 2.8$

$\times 1.4$

$\times 70$

$\times 2.24$

$\times 1.12$

$\times 70$

plants per acre

$\times 2.47$ 


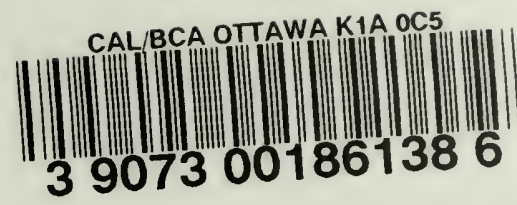


